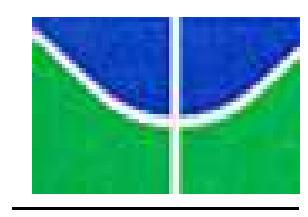

UNIVERSIDADE DE BRASÍLIA

FACULDADE DE ECONOMIA, ADMINISTRAÇÃO, CONTABILIDADE E CIÊNCIAS DA INFORMAÇÃO E DOCUMENTAÇÃO (FACE)

PROGRAMA DE PÓS-GRADUÇÃO EM ADMINISTRAÇÃO (PPGA)

VALERIA SELVA BUENO

MODALIDADES DE VIOLÊNCIA NAS RELAÇÕES DE TRABALHO EM UMA ORGANIZAÇÃO PÚBLICA FEDERAL

BRASÍLIA - DF 
VALERIA SELVA BUENO

\title{
MODALIDADES DE VIOLÊNCIA NAS RELAÇÕES DE TRABALHO EM UMA ORGANIZAÇÃO PÚBLICA FEDERAL
}

Monografia apresentada à Faculdade de Economia, Administração, Contabilidade e Ciência da Informação e Documentação (FACE), da Universidade de Brasília, como requisito à obtenção do grau de Especialista em Gestão de Pessoas.

Orientador: Prof. Dr. Marcus Vinicius Soares Siqueira

\author{
BRASÍLIA - DF
}




\section{DEDICATÓRIA}

As minhas filhas abençoadas Jessica, Paola e Alessandra as fagulhas de admiração e afeto em seus olhos, foram os alicerces dos meus dias.

As minhas amadas netinhas Julia e Ester, por trazerem alegrias e renovação ao meu ser.

A minha mãe Eremita, que mesmo à distância, cuida de $\operatorname{mim}$.

Aos meus queridos genros Rodrigo, Márcio e Rafael pelo incentivo e orações. 


\section{AGRADECIMENTOS}

Ao meu amado Deus, agradeço por tudo que Fez, por tudo que Faz e, sei que ainda Fará na minha vida, pois grandes são os Seus sonhos e boa, perfeita e agradável é a Sua vontade

Aos meus abençoados pastores e amigos, Regisnaldo e Elza pela eterna cobertura. Aos meus amigos, pelo incentivo e momentos de descontração.

Ao professor e orientador Marcus Vinicius Soares Siqueira, pela sua generosidade e por me apoiar e acreditar em mim.

A organização em que trabalho, pela promoção da minha capacitação e desenvolvimento profissional.

A todos os servidores que se dispuseram generosamente a participarem dessa pesquisa.

A todos os professores do Curso de Especialização em Gestão de Pessoas do PPGA pela dedicação ao ensino, fazendo-me agregar novos valores e conhecimentos.

Aos meus colegas de curso, pela intensa troca de experiências e pelo agradável convívio.

Enfim, a todos que fazem parte desse meu caminhar

$\mathrm{Na}$ busca da verdade e aprimoramento interior

Obrigada 


\section{RESUMO}

O presente estudo tem como objetivo analisar as modalidades de violência no ambiente de trabalho numa organização pública federal, a partir da percepção e vivência de seus servidores, considerando as especificidades desse contexto organizacional, relacionando essa questão à justiça organizacional e seu impacto nas relações institucionais. Tem como objetivos específicos identificar quais as modalidades de violência que sofrem os servidores na organização pública federal; verificar qual o impacto da violência no trabalho sobre os servidores, no nível pessoal, psicológico e laboral; analisar as percepções e experiências de violências relatadas pelos servidores no contexto organizacional; identificar como a justiça interpessoal é percebida pelos servidores da organização; identificar os sentimentos e reações que advêm da percepção e vivência da (in) justiça interpessoal. A pesquisa bibliográfica evidenciou que a violência no trabalho afeta uma parte significativa da força de trabalho, implicando em custos consideráveis tanto para os servidores em termos de saúde e em relação a seu emprego, quanto para a organização. A pesquisa foi realizada com sete servidores, todos pertencentes ao quadro de carreira de uma organização pública federal, órgão do poder executivo, sediado no Distrito Federal, mediante entrevistas individuais semi-estruturadas. Para a maioria dos entrevistados a origem da violência no trabalho reside principalmente nos relacionamentos com a chefia imediata (justiça interpessoal) e na desigualdade de tratamento. Conclui-se que a justiça organizacional é relevante para a diminuição da ocorrência de violência no trabalho.

Palavras-chave: organização pública federal, violência, justiça organizacional. 


\section{SUMÁRIO}

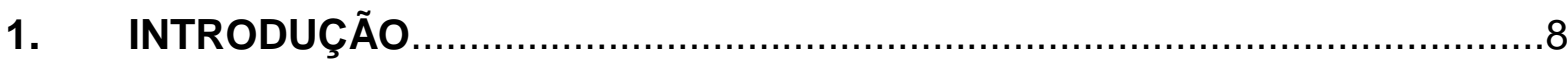

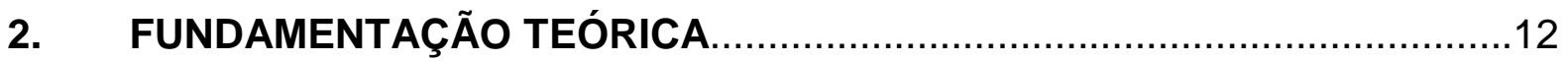

2.1 - Administração pública: a modernização do Estado................................13

2.2 - Gestão e a organização do trabalho .................................................16

2.3 - A violência no trabalho: conceitos e percepções subjetivas....................18

2.3.1 - Mobbing, bullying.................................................................21

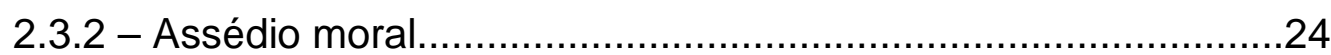

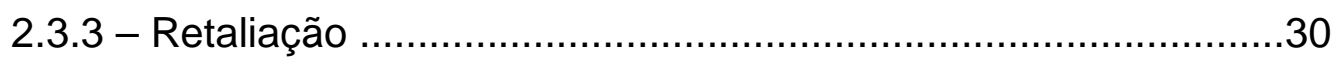

2.3.4 - Violência político-burocrática..................................................31

2.3.5 - Violência psicológica.............................................................33

2.4 - Justiça Organizacional: Conceitos e Percepções Subjetivas..................34

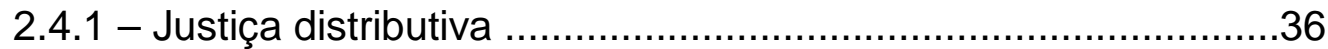

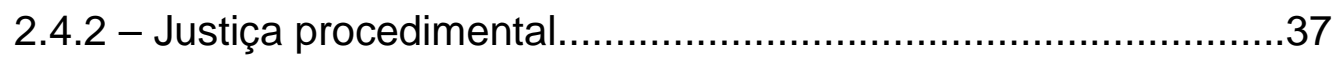

2.4.3 - Justiça interacional..........................................................

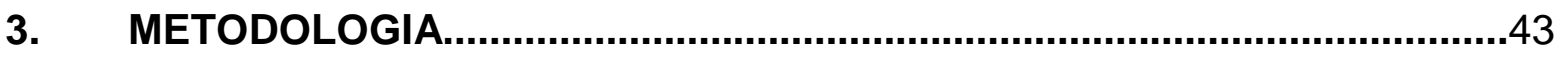

3.1 - Tipo de Pesquisa............................................................................

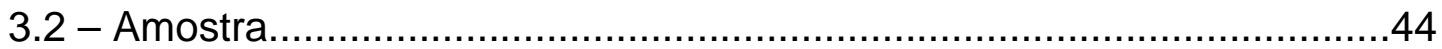

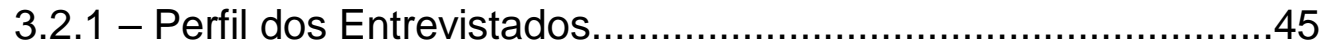

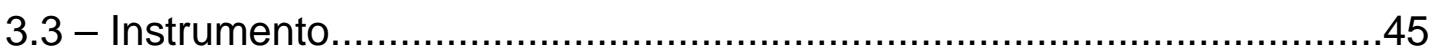

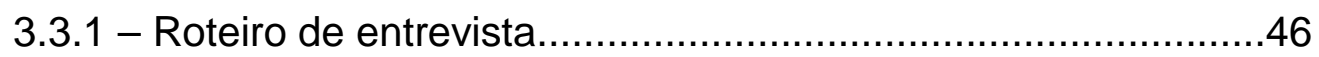

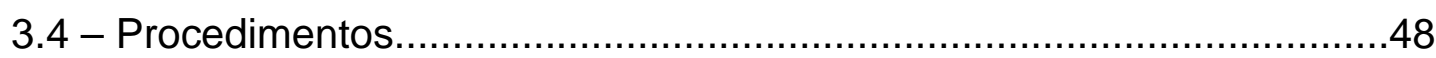

4. APRESENTAÇÃO E DISCUSSÃO DOS RESULTADOS ..........................51

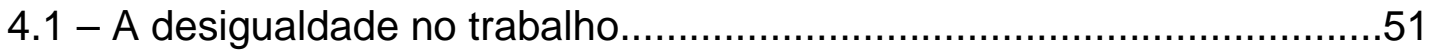

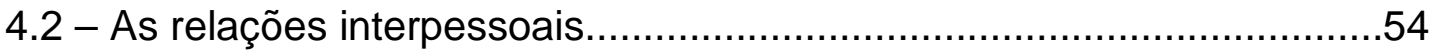

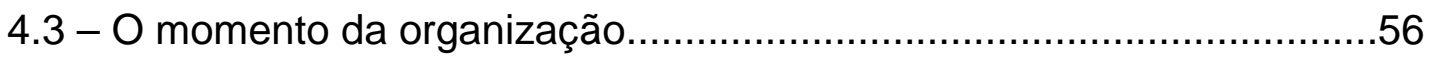

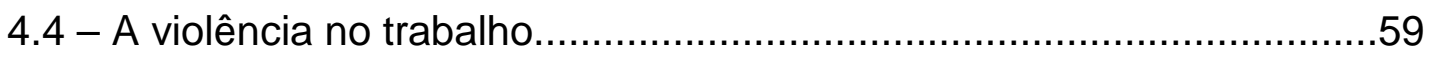

4.5 - As emoções vivenciadas no trabalho................................................. 


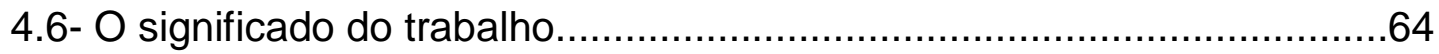

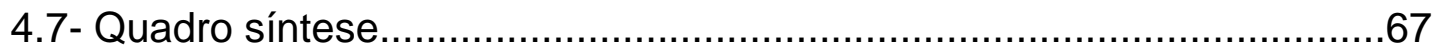

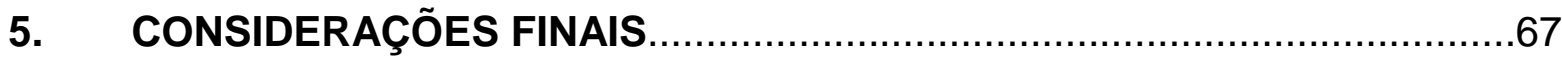

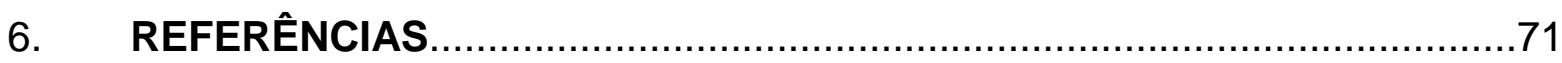




\section{INTRODUÇÃO}

Profundas mudanças socioorganizacionais são sentidas pela sociedade contemporânea. As relações de trabalho têm sofrido um impacto direto em conseqüência das transformações no mundo do trabalho, da alta competitividade, da globalização dos mercados, dos indicadores econômicos e da diminuição de postos de trabalho (MENDONÇA \& MENDES, 2005). Assim, novas formas de organizações estão surgindo, onde se observa o desaparecimento de empregos permanentes e, ao mesmo tempo, aparecem novas tecnologias e formas inovadoras de organização do trabalho. A sustentabilidade das organizações nesse cenário atual exige o surgimento de um novo estilo organizacional e uma nova organização do trabalho, com as seguintes características: flexibilidade, aprendizagem contínua, custos sempre em queda, desempenhos sempre mais elevados, equipes multiculturais e mobilidade em todos os sentidos (FREITAS et. al., 2008, p. 5).

A técnica avançou e proporcionou maior conforto ao homem, e, com isso, o trabalho atual, tornou-se mais leve do ponto de vista físico, porém, no campo psicológico, além de passar a ser uma fonte de competição, tornou-se, também, algo pesado e árduo. (BRANT \& GOMES, 2005). Os sentimentos de hostilidade, inveja e indiferença para com o próximo são reforçados por essa competição generalizada, fazendo com que outro passe a ser um objeto de ódio e ressentimento, surgindo uma nova forma de violência social, latente e induzida. (FREITAS et. al., 2008).

Freitas (2005) afirma que numa realidade marcada pela supremacia do econômico e do consumismo, o trabalho não apenas significa meio de subsistência, 
mas se apresenta como instrumento de identificação da pessoa. Nas organizações as subjetividades são fortemente influenciadas pela intersubjetividades do grupo de funcionários. Uma parte substancial da nossa identidade é dada pelo olhar do outro, ou seja, pelo reconhecimento de que somos capazes de suscitar no outro. Esse reconhecimento assume duas formas: a de que fazemos parte de algo maior e a de que somos seres singulares. Na medida em que o trabalho assume cada vez mais a centralidade na vida do indivíduo, o seu pertencimento a um grupo, no qual ele possa desenvolver e demonstrar a sua capacidade de criação e realização torna-se crucial (FREITAS et. al., 2008).

Qualquer que seja o trabalho numa organização, ele no mínimo proporcionará um bem precioso: a possibilidade de identificação social e cultural através da atmosfera de afiliação a grupos e incorporação de valores (SILVA \& HALLACK, 2006).

Para Gaulejac (2007, p. 245),

O trabalho tornou-se o elemento essencial para fixar a posição de cada um na sociedade e para canalizar as finalidades da existência sobre a carreira profissional. A esperança de melhorar a própria posição tornou-se uma aspiração que dá um sentido à história individual.

Confundem-se a vida pessoal e os sonhos com a vida organizacional, existindo uma fronteira muito tênue entre eles. (FREITAS et. al., 2008).

Em Dejours (1998) e Enriquez (2006), se encontram argumentos que sustentam as diferentes facetas das questões identitárias, considerando-as estreitamente relacionadas com a violência que acompanha o progresso social e econômico do final do século XX e do início do século XXI.

A palavra violência evoca, de imediato, imagens que tem haver com o emprego da força material: golpes, rastros de sangue, tiros, combate. Mas a 
violência, em termos gerais, é uma forma de exercício do poder mediante o emprego da força não apenas física, mas também psicológica, emocional, econômica, política.

Em suas múltiplas manifestações, a violência implica na existência de um nível acima e um nível abaixo, seja real ou simbólico, que adota habitualmente a forma de pares complementares. (SCIALPI, 2001)

No nosso cotidiano, podemos defrontar-nos com situações que nos minam as forças e que podem arrebentar-nos; tais situações constituem verdadeiros assassinatos psíquicos, porém apresentam-se como uma violência indireta, em relação a qual muito de nós, sob o pretexto de tolerância, nos tornamos complacentes, indiferentes e omissos (FREITAS, 2001).

Nas organizações, a violência e o assédio nascem do encontro entre a inveja do poder e a perversidade (FREITAS, 2001).

A identidade social está diretamente ligada ao poder, que também está diretamente ligado à justiça organizacional, sendo um ponto fundamental a observação de como os atores se percebem dentro do contexto da organização. Todas as ações e comportamentos exibidos na esfera do trabalho são frutos de auto-imagem, da justiça organizacional e do poder exercido e percebido que, por sua vez, levam a relações interpessoais, saudáveis ou não. Essas relações interpessoais são muitas vezes carregadas de violência.

Segundo Folger \& Konovsky (1989), bem como Skarlicky \& Folger (1997), as ciências organizacionais consideram que a justiça é construída socialmente e tem influência determinante nas atitudes e comportamentos no ambiente de trabalho. Quando o ambiente organizacional é aversivo, a injustiça no trabalho, de acordo com Mendonça \& Mendes (2005), coloca o trabalhador em confronto com situações que o irritam, o desgasta, amedrontam e desestimulam. 
Os estudos sobre a justiça organizacional, segundo Tamayo \& Mendonça (2004) demonstram o poder heurístico desse constructo para que se possa compreender as atitudes e os comportamentos organizacionais, reforçando a importância dos pesquisadores da área organizacional na investigação dos antecedentes e os conseqüentes desse fenômeno com a finalidade de promover a eficácia nas organizações de trabalho.

O presente estudo pretende verificar quais as modalidades de violência no trabalho estão presentes no espaço laboral de uma organização pública, com vistas a contribuir para a reflexão e debate sobre o tema, a partir da visão e vivência de servidores de uma organização publica federal, considerando as especificidades desse contexto organizacional, abordando a questão da justiça organizacional e seu impacto sobre as relações institucionais. Pretende ainda:

a - Identificar as modalidades de violência que sofrem os servidores na organização pública federal, como por exemplo: a violência político-burocrática, assédio moral, mobbing, violência psicológica e outras práticas perversas.

b - Verificar qual o impacto da violência no trabalho sobre os servidores, no nível pessoal, psicológico e laboral.

c - Analisar as percepções e experiências de violência relatadas pelos servidores no contexto organizacional, à luz do conceito de justiça organizacional na literatura contemporânea.

d - Identificar como a justiça interpessoal é percebida pelos servidores da organização.

e - Identificar os sentimentos e reações que advêm da percepção e vivência da (in) justiça interpessoal. 


\section{FUNDAMENTAÇÃO TEÓRICA}

Recentes pesquisas realizadas em alguns países europeus sugerem que a violência e o assédio psicológico têm afetado uma parte significativa da força de trabalho (DI MARTINO, 2002a; LEATHER, 2001; PAOLI \& MERLLIÉ, 2001 apud GUIMARÃES \& RIMOLI, 2006).

Ainda segundo Guimarães \& Rimoli (2006, p. 183), a Organização Internacional do Trabalho (OIT) propôs novos modelos de análise da violência no ambiente de trabalho, onde são consideradas igualmente as manifestações físicas e psicológicas, dando também importância aos atos de violência relegados ao segundo plano, tais com o amedrontamento, a intimidação ou o assédio psicológico no trabalho. Rejeita-se, a partir dessa proposta, a idéia de que:

(...) a violência no ambiente de trabalho comporte unicamente fatores pessoais e passa-se a considerá-la como resultante de uma combinação de causas relativas às pessoas, ao meio ambiente, ao ambiente de trabalho e às condições organizacionais e contratuais de trabalho.

Segundo Hoel et. al. (2001 apud GUIMARÃES \& RIMOLI, 2006) a presença da violência no ambiente de trabalho implica em custos consideráveis para os indivíduos em termos de saúde e em relação a seu emprego e para a organização, dado o impacto causado pelo absenteísmo, baixa na produtividade e rotatividade de pessoal. $\mathrm{O}$ combate à violência no trabalho traz benefícios ao individuo, à organização e à sociedade como um todo. 
Segundo Freitas et. al. (2008) a violência no passado era explicita, direta e visível, mas atualmente, no espaço laboral, encontramos uma violência sutil, ardilosa, algumas vezes indireta, sedutora e poderosa. $O$ novo ciclo de desenvolvimento capitalista está relacionado com essas sutilezas, onde os métodos de opressão, expropriação, disciplina e dominação estão cotidianamente sendo atualizados, alimentados e reconfigurados.

Faz-se necessário contribuir com a temática violência que se exerce no âmbito da organização pública federal, com vistas a, segundo Freitas (2001), despertar a consciência dos que se interessam pelas questões ligadas à subjetividade no contexto organizacional e, também, os que procuram desenvolver maneiras de torná-lo mais humano e mais decente, reduzindo práticas que degradam o ser humano e depreciam a potencialidade transformadora do seu trabalho.

\section{1 - Administração pública: a modernização do Estado}

A administração pública brasileira vem passando por muitas mudanças, e cada vez mais vem sendo pressionada pela sociedade, por melhoria dos serviços prestados, e nessa intensa exigência, busca nas empresas privadas, ferramentas que a façam mais competitiva no mercado. No entanto, esse processo de sustentabilidade ainda não excluiu por completo os procedimentos burocráticos que permeiam os atos praticados. 
A administração pública passou por várias reformas desde a primeira em 1938, que segundo De Paula (2005, p. 106) foi a "busca de um estado moderno e de uma burocracia publica profissional" até a reforma de 1995, produzida pelo antigo Ministério da Administração Federal e Reforma do Estado Brasileiro (MARE). Essa reforma investiu na administração pública gerencial que vinha sendo praticada em vários países nos anos 80.

Ainda segundo De Paula (2005), o provimento do serviço público era tratado como um negócio, fazendo migrar para a administração pública o pensamento gerencial. Nesse período foram agregados os conceitos de qualidade total, reengenharia e outros. Como o cenário mundial era de intensa competitividade e a globalização surgiu estreitando o mercado econômico, social, político e cultural, a administração pública brasileira investiu em sua sustentabilidade.

A nova administração pública gerencial

(...) tinha como objetivo melhorar as decisões estratégicas do governo e da burocracia; garantir a propriedade e o contrato, promovendo um bom funcionamento dos mercados; garantir a autonomia e capacitação gerencial do administrador público; assegurar a democracia através da prestação de serviços públicos orientados para o cidadão-cliente e controlados pela sociedade. (DE PAULA, 2005, p. 130).

Para que o modelo de gestão pretendido tivesse sucesso, era importante que a organização fosse aparelhada de "servidores públicos da maior competência, bem remunerados, e que concebam a ética do serviço público como 'o dever de servir ao cidadão'”. (BRESSER-PEREIRA E SPINK, 1998, p. 33). No entanto, apesar dos programas de governo para a implantação da nova política, a reforma foi marcada pela extinção de funções, redução de gastos, cortes de pessoal e mudanças de regime de contratação. Acrescenta-se a esse cenário, a falta de organização do trabalho contribuindo para uma imagem negativa dos servidores 
públicos, conforme admitido pelo Ministro da época, Bresser-Pereira (De Paula, 2005), estigma que até hoje se perpetua no inconsciente coletivo da sociedade.

O modelo de administração gerencial impactou o trabalho em alguns aspectos que segundo Chantal (2002) eram: aumento do volume de trabalho; queda da percepção do reconhecimento; diminuição do grau da autonomia; equipes de trabalho fragmentadas e ameaça do desaparecimento da imparcialidade, isonomia e da supremacia do interesse público.

De Paula (2005) teceu críticas à reforma, quanto ao processo decisório estar centrado num pequeno círculo burocrático, ao excesso de discricionariedade e a segregação dos escalões inferiores. A mesma autora diz que o novo modelo não substitui o anterior, pois o controle passou das mãos dos políticos para os tecnocratas, no entanto, pode-se perceber que atualmente, devido ao grande número de coalizões partidárias, que o velho esquema retornou.

Apesar da administração publica gerencial ter melhorado alguns aspectos da sua gestão, produzindo resultados que são sentidos efetivamente pelo cidadão, observa-se que houve negligencia em relação aos servidores, patrimônio mais precioso da organização. O ambiente de trabalho está fazendo com que eles adoeçam, por conta do excesso de pressão por resultados mal definidos e pelo tempo exíguo na execução das tarefas, gerando medos, incertezas, angústias e até violência. 


\section{2 - A gestão e a organização do trabalho}

A demanda de maior produtividade e adequação permanente às novas relações de trabalho, aliadas à eliminação de postos de trabalho favorecem um ambiente organizacional de autoritarismo, submissão, disciplina e competitividade, gerando nos trabalhadores instabilidade emocional e insegurança que, mesmo submetidos a condições degradantes, correndo risco de demissão, continuam trabalhando, podendo adoecer fisicamente e/ou psicologicamente (Aguiar, 2003).

A história das relações capital-trabalho nos informa sobre um campo de luta econômico que se manifesta através das relações sociais. O capitalismo desenvolveu-se segundo uma lógica própria, intensificando a criação do valor (força de trabalho) e concentra o excedente do valor criado nas mãos do capital. Para a análise da questão do poder e suas manifestações no interior das organizações é necessária a compreensão da relação social da mais-valia.

Dejours (2007a) levanta a questão de que nos fazem acreditar ou que tendemos a acreditar espontaneamente que o sofrimento no trabalho foi muito atenuado ou quase completamente eliminado pela mecanização e robotização. O sofrimento no trabalho é real. Há o sofrimento dos que temem não satisfazer ou mesmo estar à altura das imposições organizacionais que são: de horário, de ritmo, de formação, de informação, de aprendizagem, de nível de instrução e de diploma, de experiência, de rapidez de aquisição de conhecimentos teóricos e práticos (DESSORS \& TORRENTE, 1996) e de adaptação à cultura ou à ideologia da organização, às exigências do mercado, às relações com os clientes, os particulares ou o público, etc. 
Como um dos fatores de sofrimento no trabalho, Dejours (2007a) aponta o medo da incompetência, pois existe uma defasagem irredutível entre a organização prescrita no trabalho e a organização real do trabalho, isto é, por mais qualidades da organização do trabalho e da concepção, é impossível, nas situações comuns de trabalho, cumprir os objetivos da tarefa respeitando escrupulosamente as prescrições, as instruções e os procedimentos. Temos também, a pressão para trabalhar mal, isto ocorre quando o trabalhador sabe o que deve fazer, não pode fazê-lo porque o impedem as pressões sociais do trabalho.

Ainda segundo Dejours (2007a), o trabalhador se vê, de algum modo, impedido de fazer corretamente seu trabalho, constrangido por métodos e regulamentos incompatíveis entre si. As organizações devem ser compreendidas dentro de um determinado espaço social e de uma época específica. Toda significação só pode ser compreendida num formato sócio-histórico. Porém, a tendência para a rápida destruição dos padrões culturais tradicionais como a redução do significado da religião e da moral determinada pela religião; a significância reduzida dos papeis sexuais, mudando as atitudes em relação a autoridade, figuras parentais, moral sexual e atributos específicos de classes; e o declínio da ética do trabalho e a instituição de uma forma de vida consumista e hedonista, levam o individuo a uma busca pela sobrevivência, auto-realização no trabalho e o atendimento de seus desejos, onde ele se submete ao discurso organizacional das empresas modernas e se torna servo diante dos valores gerencialistas (CALGARO \& SIQUEIRA, 2006). Ocorre, assim, uma grande fragmentação dos valores e condutas pessoais e coletivas, em que a integração social começa a aparecer como problemática. Este cenário apresenta impactos nos níveis do individuo, do familiar, do organizacional e do social mais amplo, "o 
indivíduo tem sua palavra e autonomia sequestradas, deixando-se coisificar e ser tratado como servo à disposição da organização" (CALGARO \& SIQUEIRA, 2007, p.115).

Todo o trabalho nunca é neutro, segundo Heloani (2008, p. 102), ou nos ajuda na constituição de uma identidade emancipatória (processo de realização de si) ou nos induz à construção de uma identidade deteriorada, agente de estabilização e de sofrimento.

Segundo Freitas (1999) atribui-se um maior individualismo ao individuo, dentro das redes sociais estas cada vez mais virtuais, desenvolvendo contatos múltiplos com um número cada vez maior de estranhos íntimos, gerando, assim, insegurança pela falta de referências claras. Ocorre uma busca de sentido para a vida, estando esse sentido diluído num sentimento de perda, propiciando um estabelecimento de contato de convivência pacifica com a solidão, algumas vezes envolta num manto de privacidade. Importante a verificação da identidade social, pois para se entender a justiça organizacional, é fundamental observar como os atores percebem-se dentro do contexto da organização.

\section{3 - A violência no trabalho: conceitos e percepções subjetivas}

Em um contexto cada vez mais globalizado, onde a sustentabilidade da empresa está na competição, o argumento da guerra econômica segundo Gaulejac (2005), participa da construção de um imaginário social que serve de proteção ao 
exercício da dominação, onde todos os remédios são econômicos. Na organização a dominação se apresenta de forma paradoxal, pois

(...) quanto mais o profissional tem sucesso, maior a sua dependência de palco para o sucesso; quanto mais a empresa progride, mais o indivíduo regride; quanto mais ela diz que o humano é o seu ativo mais importante, mais ela o degrada em suas ações. Ou seja, lidamos com o funcionamento de um sistema que manipula as armadilhas do desejo do indivíduo; nele, o sentimento de potência o torna impotente, pois a imagem de expansão ilimitada não é outra senão a ilusão de uma projeção da imagem sem limites, que a empresa cultiva de si e a repassa por meio da sua cultura. (ENRIQUEZ, 1992; FREITAS, 1999 apud FREITAS et. al., 2008, p. 10)

Ainda sobre a dominação das empresas Dejours (1999b) propõe que os instrumentos utilizados para esse fim, não se observam em situações de violência, mas sim, na indução da tolerância à injustiça e ao sofrimento. Os instrumentos não-violentos são reforçados por processos sofisticados de comunicação interna e externa das organizações, resultando na lógica de uma distorção comunicacional. Esse tipo de dinâmica é determinante para a ocorrência da dominação simbólica não violenta e contribui para a contensão da violência "condenada", isto é, explícita, pelas organizações de trabalho. Esse método eficiente de gerenciamento tange mais a perversão do que a violência, criando assim, uma situação controversa, onde a responsabilidade moral e jurídica é imputada à pessoa que comete os atos violentos e não é imputada a quem faz funcionar o sistema. (SOBOLL \& Org., 2008, p.108).

A violência é humana e social, tendo direcionamento, intencionalidade e armadilhas peculiares, que depende da sua materialização e da categorização dos objetivos manifestos ou não, entre eles a dominação de classes, interclasses, relação de gênero, sujeição, manipulação e, também, de como ela se concretizará. A 
violência é um fenômeno complexo que desestabiliza e devasta a vida de quem a sofre, impondo dessa forma, uma nova ordem ao que estava acertado (FREITAS et. al., 2008).

A violência no trabalho manifesta-se nas formas de: agressão física, interferência nos trabalhos, ameaças, intimidação, assédio moral (incluindo o sexual ou racial), mensagens agressivas, ofensas, comportamento hostil, isolamento, perseguição por grupos (bullying), estupro, extorsão, postura agressiva, gestos rudes, provocação (mobbing), grito, roubo, homicídio, silêncio deliberado, insinuação, xingamento e outros. (SOBOLL \& Org., 2008, p. 109)

Outra forma de violência é a retaliação. Retaliação é "um ato ou efeito de revidar com dano igual ao sofrido" (HOUAISS \& VILLAR, 2001 apud MENDONÇA \& TANAYO, 2004, p. 118).

A Organização Internacional do Trabalho (OIT) lançou seu primeiro amplo relatório sobre "violência no trabalho" em 1996, onde apresentava um quadro assustador e já configurava a violência no trabalho como problema mundial. No site da International Labour Organization (www.iol.org) encontra-se uma rica e assustadora base de dados e de estatísticas sobre o mapa mundial da violência no ambiente de trabalho. A violência psicológica, dentre as formas violentas é a que apresenta o maior crescimento entre as duas pesquisas. (FREITAS et. al., 2008).

Segundo adaptações realizadas da Organização Mundial da Saúde OMS, a violência psicológica foi definida como

(...) o uso intencional do poder, incluindo ameaça de força física, contra outra pessoa ou grupo, que pode resultar em malefício para o desenvolvimento físico, mental, espiritual, moral ou social. Inclui agressão verbal, assédio moral, assédio sexual e ameaças. (SOBOLL \& Org., 2008. p.248). 
Diferentes autores em diferentes países usaram diferentes termos para falar sobre a violência psicológica. Neste presente estudo será mantida a denominação original e sua respectiva caracterização dada pelo pesquisador com vistas à melhor compreensão do desenvolvimento histórico. Dessa forma os termos mobbing, bulling, assédio moral, assédio psicológico ou terror psicológico no trabalho têm sido utilizados como sinônimo definindo a violência pessoal, moral e psicológica, vertical (ascendente ou descendente) ou horizontal no contexto laboral (GUIMARÃES \& RIMOLI, 2006). Inclui-se aqui, também, a retaliação.

\subsection{1 - Mobbing e bullying}

Muitas pesquisas foram divulgadas no meio acadêmico ao longo dos anos 80, e em 1993, Heinz Leymann lança um livro em que utiliza os termos em inglês mobbing e psicoterror (terror psicológico). Segundo Leymann, mobbing referese a um processo em que um indivíduo é escolhido como alvo, marcado para ser excluído, agredido e perseguido incessantemente por outro individuo ou grupo no ambiente laboral, sendo que essa perseguição pode vir de um colega, um subordinado ou um chefe. Algum desacordo não expresso com a vítima é o que geralmente inicia a perseguição, fazendo com que a vitima seja estigmatizada passando a ser considerada como "uma pessoa difícil", incômoda, impossível de se conviver, sendo imperativo livrar-se dela. Caso seja desencadeado esse processo de violência, sem que haja intervenção externa, tenderá a ser reforçado pela omissão e pela conivência de colegas e superiores. (FREITAS et. al., 2008). 
Acrescenta Leymann (1996, p.172) na descrição do fenômeno como "um conflito cuja ação visa à manipulação da pessoa no sentido não amigável" que essa ação merece ser analisada através de três grupos de comportamentos:

1) Manipulação da comunicação da vitima, onde são utilizados os mecanismos de negação da informação relativa ao posto de trabalho, como as funções e responsabilidades, os métodos de trabalho (a qualidade, a quantidade e os prazos do trabalho a ser realizado); a comunicação hostil explicita, com criticas e ameaças publicas; a comunicação hostil implícita, como o não dirigir palavras, ou negar cumprimento.

2) Manipulação da reputação da vitima, manifestado pela realização de comentários injuriosos, com ridicularizações publicas, relativas ao aspecto físico ou às idéias ou convicções políticas ou religiosas; realização de criticas sobre o profissionalismo da vitima; assédio sexual da vitima.

3) Manipulação do trabalho da vitima, ocorrendo pelo aumento da sobrecarga de trabalho; da atribuição de trabalhos desnecessários, monótonos e rotineiros; de atribuição de tarefas de qualificação inferior à da vitima; de atribuição de demandas contraditórias ou excludentes; de atribuição de demandas contrárias aos padrões morais da vitima; da não atribuição de tarefas; da negação dos meios de trabalho.

Suárez (2002 apud GUIMARÃES \& RIMOLI, 2006) soma um quarto mecanismo aos apresentados por Leymann que é o da manipulação das contrapartidas laborais, onde os mecanismos são a discriminação salarial, nos turnos, na jornada ou em outros direitos e, também, a discriminação quanto ao respeito, o tratamento ou no protocolo. 
Vartia (2001 apud GUIMARÃES \& RIMOLI, 2006) relata que apesar dos dados das pessoas assediadas no ambiente de trabalho seja alarmante, devese destacar que essa situação também afeta as pessoas que testemunham e presenciam episódios de assédio em seu local de trabalho, sendo que o fato de ser testemunha é um preditor altamente significativo do estresse geral e das reações ao mesmo.

Segundo Piñuel y Zabala (2001, p. 32 apud GUIMARÃES \& RIMOLI, 2006) os assediadores fazem funcionar o aparato devastador do mobbing através de ciúme e inveja, sendo essa última não somente sendo canalizada para os bens materiais da vitima, mas para as suas qualidades pessoais positivas, tais como, sua inteligência, brilho pessoal, equanimidade, entre outros.

Para Freitas (2001), a violência e o assédio nas organizações, nascem do encontro entre a inveja do poder e a perversidade. Esse poder, para Freitas et. al. (2008, p. 25) pode "ser real ou imaginário, mas ele incomoda o agressor, sendo que o atributo que o expressa pode ser sustentado em qualquer fonte como conhecimento, beleza, relacionamento pessoal ou competência”.

Em 1992, na Inglaterra, a jornalista Andréa Adams, ex-vitima de bullying, por intermédio de dois programas de debates e entrevistas com especialistas na tevê - a saber: "Um abuso de poder" e "De quem é a culpa?" desenvolvidos na emissora de televisão BBC, obteve uma grande repercussão no público, o que fez com que criasse uma ONG que leva hoje o seu nome (2006) com o objetivo de combater a violência no mundo do trabalho. Usa-se a denominação bullying, aceita no Reino Unido e Austrália, para referir-se ao comportamento ofensivo contra um individuo ou a um grupo de trabalhadores, cujos ataques são imprevisíveis, desleais, irracionais e dificilmente notados pelos outros. Refere-se 
também, ao abuso de poder que mina aos poucos a confiança e a auto-estima do individuo alvo e ao fenômeno que é visto como usado por quem detêm poder ou posição para coagir por meio do medo, da perseguição, da força ou de ameaças. Visto dessa forma, o bullying ocorre de forma ascendente (de uma condição superior para uma subordinada), limite que não é compartilhado por outros pesquisadores. $O$ termo bullying anteriormente era usado, genericamente para descrever situações de humilhações, vexames, constrangimentos ou ameaças que crianças infligiam umas às outras, especialmente no contexto escolar (FREITAS et. al., 2008).

\subsection{2 - Assédio moral}

Em 1998, Marie-France Hirigoyen, psiquiatra, psicanalista e psicoterapeuta familiar, com formação em "victimologia" nos Estados Unidos e na França, utilizou, pela primeira vez, o termo "assédio moral", por meio do lançamento de seu livro Le harcèlemente moral: La violence perverse au quotidien, e, iniciou um grande debate seja no âmbito familiar, seja no mundo do trabalho.

Em seu segundo livro, Mal-estar no trabalho: redefinindo o assédio moral, Hirigoyen (2002, p. 17) aprimora o conceito contido no primeiro livro e propõe a seguinte definição:

(...) assédio moral no trabalho é definido como qualquer conduta abusiva (gestos, comportamento, atitude...) que atende, por sua repetição ou sistematização, contra a dignidade ou integridade psíquica ou física de uma pessoa, ameaçando seu emprego ou degradando o clima de trabalho. 
No nosso dia a dia, há a possibilidade de nos defrontarmos com situações que nos minam as forças e podem nos arrebentar. Essas situações são verdadeiros assassinos psíquicos, mas apresentam-se como uma violência indireta, na qual, muitos de nós, sob o pretexto da tolerância, podemos nos tornar complacentes, indiferentes e omissos. (FREITAS, 2001)

O assédio, para Hirigoyen (2002), pode ocorrer em diversas direções, podendo partir tanto da chefia e de colegas como partir de subordinados. Não há a necessidade de haver um conflito instaurado entre o agressor e a vitima. Aliás, para Freitas et. al. (2008, p. 26) os conflitos geralmente fazem emergir as divergências e as discórdias, possibilitando a sua negociação ou resolução. Nos casos de assédio, contudo, a vítima pode ignorar o problema por bastante tempo, uma vez que, freqüentemente, as pessoas à sua volta assistem em silêncio ao desenrolar da trama.

O assédio moral pode surgir de forma insignificante, podendo ser confundido com uma brincadeira de mau gosto, dificultando assim, a consideração séria pela vítima e a sua formalização como problema organizacional.

(...) a característica principal é a repetição, é somente depois de ser regularmente acuada que a vítima percebe que os ataques se multiplicaram e o seu estado de inferioridade ou fragilidade torna mais difícil a sua reação. Essas agressões geralmente não são infligidas diretamente, mas elas são constantes o suficiente para provocar uma queda de auto-estima da vítima, que se sente humilhada, usada e suja. Esses sentimentos contribuem para o seu isolamento, fortalecendo o círculo vicioso, ou seja, quanto mais isolada, mais frágil e mais atacada. (FREITAS et. al., 2008, p. 26).

A respeito da vitima, Freitas (2001, p.11) diz que, em principio,

(...) não traz nenhuma patologia ou fraqueza psíquica. Geralmente, é o assédio que desencadeia a reação, posto que a vítima reage ao 
autoritarismo. É pois, a sua recusa a submeter-se à autoridade, apesar das pressões, que a designa como alvo.

Para Heloani (2008, p. 98), normalmente, essas vítimas são pessoas com personalidade, que se posicionam, algumas vezes questionando privilégios, e não têm grande talento para o fingimento. Tornam-se os alvos das agressões justamente por não se deixarem dominar.

Quanto ao agressor, Heloani (2008, p. 98) relata que

Algumas pessoas sentem-se mais poderosas, seguras e até mesmo mais autoconfiantes à medida que menosprezam e dominam as outras. Ambiciosos e invejosos, esses indivíduos procuram aproveitar-se do trabalho alheio, sugando energias e realizações de outros para montarem uma pseudo-imagem de si próprios: verdadeiros "salvadores da pátria".

Esta postura aliada à questão da hipercompetitividade, produto resultante de um intenso processo de globalização, pode levar com facilidade, do ponto de vista do autor, ao assédio moral (HELOANI, 2008). A existência de competição exacerbada no contexto organizacional faz com que tudo seja justificado em prol da competitividade, dessa forma, produz um álibi permanente para que as exceções se transformem em regras gerais e comportamentos degradantes configurem como normais, pois a competitividade passa a ser sinônimo de competição cruel a qualquer preço. A supervalorização de hierarquias faz com que as chefias sejam intocáveis e inquestionáveis, tornando os comportamentos decentes e democráticos como uma falha ou uma debilidade diante da supremacia da chefia, verdadeiros semideuses, que se refestelam na impunidade. (FREITAS et. al., 2008).

Existem quatro critérios de definição do assédio moral que são a habitualidade, a pessoalidade, o local e a intenção de prejudicar. A partir deles, o 
assédio moral é definido como um conjunto de comportamentos hostis, repetitivos e prolongados que articulados, se configuram como armadilhas. (REZENDE, 2006; SOBOLL, 2008).

Araújo (in SOBOLL \&Org., 2008, p. 81) também descreve os critérios com mais freqüência utilizados para a identificação do assédio moral são: a repercussão da conduta abusiva na saúde física e psicológica da vítima, a periodicidade e a durabilidade do ato faltoso, as espécies de condutas abusivas, a sua finalidade, o perfil e a intencionalidade do agressor. Para o critério "repercussão da conduta abusiva na saúde física e psicológica da vítima" só há assédio se houver a configuração dessa situação. Essa exigência condiciona o reconhecimento do assédio moral à sua subjetividade, ignora os caos em que a vítima seja mais resistente à agressão ou aqueles em que seus problemas físicos ou psíquicos transparecem apenas após o término da violência.

Hirigoyen (2001, p.p. 108-109) identificou e catalogou comportamentos tipos de maus tratos, ressaltando que devem ser repetitivos e frequentes, podendo ser justapostos, isto é, o agressor pode utilizar-se de diversos tipos ao mesmo tempo, tornando o ataque mais poderoso e rápido no intento de destruir o outro. São eles, segundo Freitas et. al. (2008):

1) Deteriorização proposital das condições de trabalho, configurando-se como a retirada da autonomia da vitima, não transmitir informações úteis à realização do trabalho; contestação sistemática das opiniões da vitima; criticas ao trabalho de forma injusta ou exagerada, entre outros.

2) Isolamento e recusa de comunicação, configurando-se como interrupções constantes da fala da vitima; falta de diálogo promovido por seus colegas e 
superiores hierárquicos; comunicação efetuada exclusivamente por escrito; todos os contatos são recusados inclusive o visual; segregação feita pelos outros; presença ignorada; proibição de colegas falarem com a vitima; vitima não pode falar com ninguém e a administração recusa qualquer pedido de entrevista.

3) Atentado contra a dignidade, utilização de insinuações desqualificadoras; de gestos de desprezo diante da vitima; vitima é desacreditada diante de todos; rumores sobre problemas psicológicos da vitima são espalhados; zombaria das deficiências físicas ou de aspecto físico da vitima; sofre imitações e caricaturas; criticas a sua vida pessoal; zombaria de suas origens e naturalidade; implicância com suas crenças religiosas ou convicções políticas; atribuição de tarefas humilhantes; injurias com termos obscenos ou degradantes.

4) Violência verbal, física ou sexual, configurando-se como ameaças de violência física; invasão de privacidade; perseguida e espionada em sua vida pessoal; não atentam para os problemas de saúde; destruição de propriedade material da vitima; assedio ou agressão sexual.

Em relação à realidade brasileira, destaca-se a utilização dos procedimentos mais corriqueiros como dar instruções confusas e imprecisas; bloqueio do andamento do trabalho; atribuição de erros imagináveis e ignorar a presença dos trabalhadores (BARRETO, 2003).

Segundo Maciel et. al. (2007), não existem dúvidas quanto às consequências ao trabalhador pela exposição ao assédio moral no trabalho, cujas principais são a depressão, ansiedade, sociofobia, ataques de pânico, baixa autoestima, desordens psicossomáticas tais como insônia, melancolia, apatia, falta de concentração, sudorese, tremores e outros sintomas comportamentais. 
Há um consenso de que os antecedentes organizacionais do assédio moral se originam de condições laborais que levam ao estresse. Essas condições são a pressão pela produção, gerenciamento do trabalho através de metas e objetivos e, também, outros aspectos normalmente relacionados aos processos de reestruturação produtiva e a introdução de novas tecnologias de gestão, além de possuírem um forte componente cultural (EINARSEN, 2005; LIEFOOGHE \& DAVEY, 2001; SALIN, 2005; ZAPF, 1999 apud MACIEL et. al., 2007, p.119).

Ainda segundo Maciel et. al. (2007), é bastante propício o surgimento do assédio moral num ambiente onde as relações hierárquicas autoritárias predominam, facilitando, assim, o desequilíbrio de poder e a incapacidade do assediado em defender-se das agressões. Concluem que a predominância de estilos de lideranças autocráticas pode ser um indicio favorável para a ocorrência do assédio moral.

Barreto (2003b) realizou no Brasil uma pesquisa com 2.072 trabalhadores, de 97 empresas do setor químico, farmacêutico, plástico e similares, em São Paulo. A metodologia utilizada foi qualitativa e estimou -se que $42 \%$ dos trabalhadores vivenciaram histórias de humilhações e constrangimentos, evidenciando, assim, o impacto do assédio moral nas organizações. (MACIEL et. al., 2007, p. 119).

Algumas situações são equivocadamente ditas como assédio moral, pois são destrutivas e maldosas, mas não necessariamente mal-intencionadas e nem sempre conscientes, conforme foram descritas por Hirigoyen (2002) como: gestão por estresse, gestão por injúria, agressões pontuais, erros de gestão, transmissão de estresse e transmissão da perversidade. 


\subsection{3 - Retaliação}

Retaliação é outra modalidade de violência no ambiente de trabalho, gerada a partir da experiência de injustiça vivenciada pelo trabalhador. Para Mendonça e Tamayo (2004) os estudos de retaliação demonstram como principal antecedente a percepção de justiça, podendo ocorrer em diferentes contextos, abarcando relações interpessoais, organizacionais e societais. Ocorre de maneira explícita (flagrante) ou sutil, podendo causar danos psicológicos ou físicos.

Ainda segundo esses autores, pesquisas insinuam que pessoas que se percebem injustiçadas no trabalho, tendem a encontrar maneiras de contra-atacar e descontar. Essas retaliações podem diretas ou indiretas, podendo ser direcionadas para a organização ou para alguém dentro da organização.

(...) a retaliação aglutina dimensões perceptivas, avaliativas, afetivas e conativas. Em conjunto essas dimensões envolvem a indignação com a injustiça, o ressentimento, a raiva, a severidade da perda, o merecimento da retribuição, a conduta imprópria da chefia e a tendência consciente para reagir com a retaliação. (MENDONÇA \& TAMAYO, 2004, p. 130).

Os trabalhos de Skarlicki et. al. (1999) consideram como causa da retaliação, além da injustiça percebida, as variáveis de personalidade. Os resultados do estudo reforçam a percepção interacional para a retaliação no trabalho; A relação entre justiça e comportamentos retaliatórios é moderada pelas variáveis de personalidade.

Mendonça (2003) afirma que a retaliação é definida como comportamentos que sofrem influencia de atributos pessoais dos atores organizacionais. 


\subsection{4 - Violência-político burocrática}

Scialpi (1999) aborda outra modalidade de conduta violenta, denominada de violência-político burocrática. Para esse tipo de violência é muito difícil encontrar provas contundentes, apesar de haver claros indicadores que são expedientes que revelam o que está acontecendo. A violência-político burocrática tem impacto sobre a saúde dos servidores e sobre os resultados da gestão das organizações, e, se converte em modelo autorizado (CORIA, 1994 apud SCIALPI, 1999) e oferece um suporte instrumental estratégico para a corrupção, fenômeno esse, que atualmente começa a ser combatido por organizações de controle. Para essa autora, a perpetuação da corrupção na administração pública ocorre primeiramente pelas condutas de violência na gestão de pessoas, e em segundo lugar pela impunidade absoluta dos agressores e assediadores. Por último, tal perpetuação ocorre pelo fato das vitimas sofrerem da síndrome da indefesa aprendida. Desta forma se mantém o Estado de direito em agonia.

Os efeitos devastadores da violência-político burocrática derivam da coexistência de dois fatores: primeiro essa violência é perpetuada por funcionários políticos e também pelo pessoal hierárquico e administrativo de carreira do alto escalão da administração pública que tem a responsabilidade social, legal e administrativa de cuidar dos servidores públicos e de cumprir e fazer cumprir as normas administrativas vigentes; segundo, pela transformação do caráter protetor em caráter violento ocorre num ambiente laboral e num discurso que destrói ou deturpa os significados e renega essa transformação.

O desamparo aprendido em que se encontram as pessoas afetadas pela violência político-burocrática, encobre e perpetua a existência e o 
funcionamento das relações violentas mais freqüentes e rotineiras da nossa sociedade, onde não se percebe o exercício da força material e por isso, tem sido naturalizadas e normatizadas (IZAGUIRRE, 1998 apud SCIALPI, 1999).

Por intermédio de casos estudados, verificou-se que as manifestações desse tipo de violência que atingem os servidores públicos, são as seguintes: aberta violação das normas vigentes; critérios irracionais de seleção de pessoal; concursos fraudulentos; ascensão por indicação, corporativa ou por afinidade à cargos de direção na estrutura organizacional pública e dos recursos reservados; existência de regimes de privilégio e de onerosas consultorias financiadas por organismos internacionais que contribuem para aumentar a divida externa; demissões injustificadas; sistema de capacitação direcionada exclusivamente à alguns beneficiados, e outras situações mais.

Para Oszlak (1994), são muitas as modalidades de sofrimento que os funcionários públicos vivenciam. Algumas delas são:

(...) as violações das normas vigentes, os critérios de seleção de pessoal, concursos espúrios, corporativismo ou amiguinhos dos cargos de direção, onde o desempenho da excelência profissional é realizado mediante critérios perversos, avaliações de equivalências escandalosas e desiguais, isolando o trabalhador. (OSZLAK, 1994 apud LAZZAROTO et. al., 2006, p. 123).

Scialpi (2001) afirma que a violência burocrática é perpetuada pelos administradores e servidores, precisamente aqueles que têm a responsabilidade de respeitar e fazer respeitar as normas administrativas.

Ainda, segundo Scialpi (1999) temos como efeitos do sofrimento impetrado pela violência-político burocrática aos servidores, a discrepância cognitiva, os processos de fuga e ataque, lavagem de cérebro e a síndrome de Estocolmo. 


\subsection{5 - Violência psicológica}

Quanto aos atos de violência, pesquisas brasileiras (BARRETO, 2005 apud FREITAS et. al., 2008, p. 57) identificam

(...) as condutas verbais e as atitudes que ameaçam, constrangem e desqualificam, características da violência psicológica no local de trabalho, resultando em $80 \%$ de práticas que revelam o exercício da tirania, em uma nova roupagem, isto é, a violência sutil.

A violência psicológica é entendida como qualquer situação no qual um homem ou mulher passam a ser alvo de atos injustos e ilícitos. Esses atos são isolados, descontinuados, desordenados e que retratam as agressões verbais, coações, constrangimentos, injurias, maledicências, fofocas, desqualificações, desmoralizações, agressões gestuais, ameaças, ofensas, humilhações, discriminações e outros atos que ocorrem de forma pontual. Mesmo quando os atos se configuram pontuais, isolados e anárquicos, desnudam os excessos do exercício do poder, da intensa exploração, da sobrecarga de trabalho, a pressão e também a opressão para produzir mais e mais, não importando como e em quais condições (FREITAS et. al., 2008, p. 58).

Procurar as causa de todas as situações e fatos que ocorrem em um espaço laboral e não na mente das pessoas, é uma cautela necessária, pois sem isso, histórias e relações antagônicas sumirão no quadro das relações materiais existentes, como se os indivíduos não soubessem o que fazem, como fazem e por que fazem. (FREITAS et. al., 2008). 


\section{4 - A justiça organizacional: conceitos e percepções subjetivas}

Todas as ações e comportamentos exibidos na esfera do trabalho são frutos de auto-imagem e justiça organizacional, que por sua vez, propiciam relações interpessoais saudáveis ou não. Desta forma, buscou-se discorrer sobre a justiça organizacional, com vistas a compreender as variáveis no ambiente de trabalho que possam fomentar o surgimento da violência no espaço laboral.

As ciências organizacionais consideram que a justiça é construída socialmente e tem influência determinante nas atitudes e comportamentos no ambiente de trabalho, segundo Folger \& Konovsky (1989) e Skarlicky \& Folger (1997). Quando o ambiente organizacional é aversivo, a injustiça no trabalho, de acordo com Mendonça \& Mendes (2005), coloca o trabalhador em confronto com situações que o irritam, o desgasta, amedrontam e desestimulam.

Em pesquisa feita por Mendonça \& Mendes (2005) numa empresa pública, verificou-se que, nos relacionamentos interpessoais, os trabalhadores têm vivência de sofrimento em função da predominância do sentimento de injustiça nas relações entre chefia e subordinados. A queixa apontada foi de que a chefia não proporciona ao subordinado o direito à defesa, provocando um clima de temor e de "medo de ousar". Há um grande desgaste emocional pela falta de respeito e pelas freqüentes grosserias. Os ocupantes de cargo de chefia, também se sentem insatisfeitos e desrespeitados pela maneira com que seus superiores os tratam. Evidencia-se, assim, uma vivencia de sofrimento tanto pela chefia quanto pelos subordinados, onde o agente do sofrimento é a sua chefia superior em ambos os casos. 
A percepção do suporte organizacional é outro fator que pode gerar estresse, sendo que essa percepção está diretamente ligada às crenças e expectativas do trabalhador acerca da retribuição e reconhecimento dado ao seu trabalho pela organização. (TAMAYO \& TRÓCCOLI, 2002)

\begin{abstract}
Altas expectativas ou expectativas não atingidas com relação aos desafios no trabalho, a recompensa, ao reconhecimento, ao avanço na carreira e a outros aspectos laborais podem gerar estresse. (CORDES \& DOUGHERTY, 1993 apud TAMAYO \& TRÓCCOLI, 2002, p.39).
\end{abstract}

No Brasil, o modelo de justiça organizacional caracterizado em 3 dimensões (distributiva, processual e interacional) é o mais utilizado por apresentar intensas correlações, além de ser mais acessível à população geral, sendo testado por vários autores (MENDONÇA et. al., 2003; CROPANZANO \& GREEBERG, 1997; FOLGER \& BIES, 1989; TYLER \& BIES, 1990; BROCKNER \& WEISENFELD, 1996 apud MEIRELLES, 2006).

Para Mendonça \& Mendes (2005, p. 495), fica evidenciado o caráter multidimensional da justiça organizacional

À medida que os resultados englobam a distribuição e alocação de recursos (justiça distributiva), os procedimentos seguidos, assim como decisões tomadas para distribuir tais recursos (justiça de procedimentos formais) e o tratamento interpessoal entre gestores e empregados nas interações institucionais (justiça de procedimentos interacionais.

Um aspecto importante foi trazido por Shapiro \& Kirkman (2001) com o conceito de justiça antecipada, segundo o qual experiências iniciais de injustiça podem acarretar a expectativa de que elas irão se repetir no futuro. Essa forma de injustiça esperada e não necessariamente vivenciada, pode se aplicar a qualquer 
das formas de justiça descritas acima, e a ocorrência potencial de uma ou mais dessas formas pode ser antecipada pelos trabalhadores, principalmente em tempos de mudança organizacional. A injustiça antecipada provoca sentimentos, atitudes e comportamentos organizacionais negativos, autodefensivos e contra-produtivos. Isso tem impacto não só a nível individual, como também, no nível organizacional porque os efeitos acumulativos das antecipações negativas acabam em última análise por mudar a cultura organizacional.

A justiça distributiva, justiça processual e justiça interacional são as percepções de justiça organizacional que se pretende abordar nesse trabalho.

\subsection{1 - Justiça distributiva}

Segundo Tamoyo \& colaboradores (2004), a justiça distributiva postula que uma dada distribuição de resultados é percebida como justa, se a razão entre contribuição e resultados de um trabalhador é igual a razão entre contribuições e resultados de um outro com quem se compara. A percepção de iniqüidade, favorável ou desfavorável, gera-Ihe tensão e motiva-o a reduzi-la, recorrendo, para tanto, a várias estratégias: se sentir sub-recompensado, pode reduzir seu empenho no trabalho, reivindicar aumento salarial, engajar-se em greves ou buscar uma atividade mais recompensadora. Na impossibilidade de uma mudança real nesses elementos, resta-Ihe, ainda, o "abandono de campo" (absenteísmo ou rotatividade) ou estratégias psicológicas para lidar com o sentimento de injustiça, que não mudarão sua situação real, mas alterarão sua percepção dela. Depreende-se, assim, que a 
justiça distributiva tem fortes implicações no contexto organizacional, do qual a distribuição de resultados é parte integrante.

Assim, quando um determinado resultado é percebido como injusto, tal percepção gera certas emoções, tais como raiva, ressentimento, tensão e culpa; afeta as cognições, como por exemplo, a distorção cognitiva dos investimentos feitos no trabalho e respectivos resultados, próprios ou de outras pessoas; e desencadeia comportamentos, tais como decréscimos no desempenho do trabalho ou abandono de emprego.

Na esfera pública o abandono de emprego tem um percentual muito baixo, pois o servidor investiu tempo e dinheiro para os estudos com vista à sua aprovação no concurso público. O êxodo no serviço público, isto é, passasse num concurso e logo em seguida almeja outro concurso com mais vantagens, está chegando a níveis críticos, principalmente no Executivo. No que tange ao decréscimo de desempenho, também ocorre, mas com a estabilidade no serviço público o servidor não se importa, é uma forma de retaliação, e logo o seu trabalho é absorvido por outro servidor.

\subsection{2 - Justiça processual}

A justiça processual, segundo Greenberg (1990), é a justiça percebida das políticas e procedimentos utilizados para tomar decisões. Algumas formas de aumentar as percepções dessa justiça é providenciar voz nos processos de tomada de decisão, oportunidade para corrigir erros de julgamento, aplicação igualitária e não enviesada das regras, e, tomar decisões baseando-se em informações precisas. 
Mendonça \& Mendes (2005) verificaram, em sua pesquisa, que os trabalhadores têm receio de expressar opiniões que contrariem o pensamento vigente na instituição. O medo de perder o emprego é grande, por isso algumas pessoas aceitam as injustiças passivamente.

Leventhal (1980) descreve que um processo justo deve respeitar seis critérios: ser aplicado de forma consistente ao longo do tempo e entre os indivíduos, não ser enviesado, assegurando que uma terceira parte não tenha interesse particular numa decisão específica, assegurar que na tomada de decisões seja recolhida e utilizada informação correta, garantir a existência de mecanismos para corrigir qualquer decisão incorreta ou imperfeita, assegurar que as opiniões dos diferentes grupos afetados pela decisão são tidas em consideração, estar conforme o padrão ético e morais prevalecentes. Resumindo esses critérios como, consistência, isento de tendenciosidade, exatidão da informação, correção, representatividade e eticalidade.

\subsection{3 - Justiça interacional}

Por último, a justiça interacional introduzida por Bies e Moag (1986), segundo Tamoyo \& colaboradores (2004), que ressalta o aspecto social das práticas organizacionais, particularmente o tratamento interpessoal e a comunicação da gerência com os trabalhadores, que abrangem aspectos como polidez, respeito e honestidade nas relações entre a fonte e o receptor da justiça. A justiça interacional relaciona-se à qualidade do tratamento interpessoal recebido pelo empregado, no caso, servidor, durante a aplicação dos procedimentos. Dessa maneira ela equivale 
ao lado humano das práticas da organização, ou seja, ao modo pelo qual os gerentes se comportam em relação aos recebedores da justiça (COHEN-CHARASH \& SPECTOR, 2001 apud FERREIRA et. al., 2006).

Quando um trabalhador percebe injustiça interacional, é de se esperar que ele reaja mais desfavoravelmente e tenha menor comprometimento, e outras atitudes mais negativas em relação a seu supervisor direto, do que à organização propriamente dita. Tais percepções, baseadas na justiça interacional, são devidas à extensão com que os trabalhadores percebem que a fonte da injustiça não é o procedimento formal em si mesmo, mas a pessoa que o implementa, no caso, como foi dito anteriormente, o chefe imediato.

Os estudos sobre o impacto da justiça sobre o funcionamento organizacional mostram que quando os empregados percebem os procedimentos como justos ficam menos preocupados com aqueles injustos (CROPANZANO \& FOLGER, 1989; BARLING \& PHILLIPS, 1993 apud TAMAYO \& MENDONÇA, 2004). Para Morgan (1991), a justiça interacional é mais importante do que os procedimentos formais para determinar o comportamento dos empregados nas organizações (TAMAYO \& MENDONÇA, 2004).

Bies e Moag (1986, p. 44) introduziram o conceito de justiça interacional como um dos três segmentos da justiça organizacional e se refere às concepções da pessoa sobre a "qualidade do tratamento interpessoal recebido nos procedimentos organizacionais".

Quatro critérios são identificados por Bies e Moag (1986) que caracterizam a justiça interacional: 
1) Respeito - englobando aspectos de tratamento em relação aos empregados, de forma correta e cortês, respeitando a individualidade e tendo em consideração os direitos de cada trabalhador;

2) Retidão - evitar comentários impróprios ou ofensivos a dignidade individual;

3) Honestidade - engloba aspectos de tratamento sincero, verdadeiro, imparcial e desprovido de enviesamentos pessoais;

4) Justificação - abarca elementos como explicações ajustadas às decisões e das bases que as fundamentaram, incluindo feedback realizado dentro do prazo adequado e sensibilidade às necessidades pessoais. (SOTOMAYOR, 2007).

Alguns autores (COLQUITT et. al., 2001; Greenberg, 1993; Rego, 2002), então, desdobraram a justiça interacional em dois diferentes aspectos: a interpessoal e informacional. A justiça interpessoal associa-se ao grau de tratamento digno e respeitoso que os gestores dispensam aos seus empregados envolvidos nas decisões distributivas e procedimentos por eles adotados. A justiça informacional refere-se ao grau que os empregados recebem informações e explicações de seus gerentes sobre tais decisões e procedimentos (FERREIRA et. al., 2006).

Percebe-se com o exposto que a vida no trabalho ocorre em cenário de atitudes, emoções e sentimentos de enorme diversidade, acrescentado de uma infinita gama de tomadas de decisões, competitividade, eventos imprevisíveis do cenário externo e muito mais. Todo esse aglomerado de variáveis reproduz e influência a forma particular de cada indivíduo lidar com a realidade.

Para Sucesso (2002) qualidade de vida no trabalho não decorre apenas de salário acima do mercado e de invejável plano de benefícios, incluindo-se aqui, a estabilidade do servidor público. Resulta também do tratamento humano, da 
gentileza, de leveza das relações, da possibilidade de expressão dos pontos de vista divergentes, do relacionamento sincero, do respeito aos ausentes e do orgulho do que se faz. Atenção, elogio e consideração constituem ingredientes indispensáveis quando se busca lealdade, qualidade e produtividade.

Segundo a mesma autora, as emoções experimentadas nas relações diárias criam uma atmosfera característica em cada organização, ou mesmo em cada departamento, uma vez que o ambiente de trabalho nem sempre é o mesmo em todas as unidades. Cada setor vive clima diferente, refletindo a forma de tratamento particular entre os membros, uma maneira própria de discutir problemas, a forma como os lideres conduzem o trabalham e lidam com as pessoas, com o erro, o quanto estão dispostos a ouvir, a reforçar o que vai bem. Grande parte dessa forma de reação é determinada pela história de vida, que configura a maneira com que a pessoa lida com emoções que permeiam as relações interpessoais.

Siqueira e Gomide Jr. (2004) afirmam que todo individuo no decorrer de sua vida, forma vínculos com pessoas, grupos, instituições e, de forma particular, estabelece vínculos (afetivos, sociais e econômicos, etc.) com o trabalho. As percepções da justiça organizacional são poderosos determinantes desses vínculos. Assim comprometimento afetivo, cidadania organizacional e cooperação espontânea, vínculos mais altruísticos estariam ligados à justiça processual, e a satisfação com salário e cooperação compulsória, de natureza mais egoística estariam ligados à justiça distributiva. Ainda segundo esses autores, a ocorrência de situações de injustiça organizacional, na forma de tratamento interpessoal, na distribuição de seus recursos e nos seus procedimentos internos, podem provavelmente contribuir para o surgimento da expressão da raiva, agressividade, além da disseminação da retaliação. Corroborando com o exposto, Beugré (1998 
apud ASSMAR et. al., 2005) afirma que a retaliação poderia ainda assumir a forma de agressão e violência no trabalho. 


\section{METODOLOGIA}

\section{1 - Tipo de pesquisa}

A finalidade da pesquisa qualitativa, segundo Bauer e Gaskell (2008), é explorar o espectro de opiniões, as diferentes representações e a variedade de pontos de vista sobre um determinado assunto.

De acordo com Godoy (1995) esse tipo de pesquisa envolve a compreensão dos fenômenos, segundo a perspectiva dos integrantes da situação em estudo, envolvendo também, a coleta de dados descritivos sobre as pessoas, lugares e processos interativos, via comunicação direta do pesquisador e sujeitos da amostra.

O presente estudo compreende uma pesquisa qualitativa, de caráter exploratório, visando verificar e analisar as percepções de alguns servidores sobre as modalidades de violência nas relações de trabalho na organização pública federal em que trabalham. Uma vez que existe pouco conhecimento acumulado e sistemático sobre o assunto, pretende-se que o estudo possa contribuir para ampliar o debate e, também, propiciar uma reflexão sobre a violência dessa categoria de trabalhadores. 


\section{2 - Amostra}

A pesquisa foi efetuada numa organização pública federal, órgão do poder executivo, sediada no Distrito Federal, com representação em todo território nacional. A organização é composta por:

a) Estagiários de nível superior que atuam em todas as áreas, sendo necessário que o conteúdo programático do curso de graduação tenha correlação com as atividades da unidade em esteja estagiando;

b) Servidores terceirizados que executam serviços de limpeza, vigilância, manutenção predial e recepção;

c) Servidores requisitados de outros órgãos da administração pública;

d) Servidores do quadro de pessoal, de nível superior, com formações acadêmicas diversas, admitidos por concurso público, ocupantes ou não de funções comissionadas.

Nessa pesquisa optou-se por utilizar uma amostra não-probabilística, por acessibilidade, levando-se em consideração o fácil acesso aos participantes.

Participaram da pesquisa 7 (sete) servidores a que se refere a alínea "d" que compõem a carreira, sendo 3 (três) de cargo de mais elevado dentro da carreira, porém todos os servidores são (4) ou foram (3) ocupantes de cargo de chefias. 
Entre os servidores entrevistados, todos possuem curso superior, 4 são do sexo masculino e 3 do sexo feminino. A faixa etária varia de 38 a 54 anos, a maioria (6) possui mais de 9 anos de exercício na organização, sendo que apenas um possui 5 anos.

\subsection{1 - Perfil dos entrevistados}

\begin{tabular}{l|ccccc} 
ENTREVISTADO & SEXO & CARGO & $\begin{array}{c}\text { TEMPO NA } \\
\text { ORGANIZAÇÃO }\end{array}$ & $\begin{array}{c}\text { FUNÇÃO } \\
\text { COMISSIONADA }\end{array}$ & IDADE \\
\hline № 01 & Masculino & Auditor & 16 anos & Já exerceu & 47 anos \\
№ 02 & Feminino & Auditor & 23 anos & Exerce & 43 anos \\
№ 03 & Masculino & Auditor & 15 nos & Já exerceu & 41 anos \\
№ 04 & Masculino & Analista & 16 anos & Já exerceu & 50 anos \\
№ 05 & Feminino & Analista & 09 anos & Exerce & 40 anos \\
№ 06 & Masculino & Analista & 33 anos & Exerce & 54 anos \\
№ 07 & Feminino & Analista & 05 anos & Exerce & 38 anos
\end{tabular}

\section{3 - Instrumento de coleta de dados}

Para a coleta de dados no presente estudo, foram realizadas entrevistas individuais semi-estruturadas, seguindo roteiro previamente definido, com o objetivo de analisar as percepções e experiências de violência vivenciadas por servidores de organização pública, no contexto organizacional, verificando se há correlação dessa violência e a percepção de justiça organizacional. 
Esse "modelo" de entrevista permite ao entrevistador, fazer adaptações se assim julgar necessário, mesmo partindo de um roteiro básico (LUDKE, 1986 apud CAMPOS, 2006), por causa da natureza pessoal do tema. Os relatos dos servidores entrevistados tiveram por base suas vivências pessoais atuais, tendo também relatado, situações de outros servidores e do momento atual do ambiente organizacional.

\subsection{1 - Roteiro de entrevista}

Não foi encontrado um roteiro de entrevista confeccionado ou utilizado por outros autores que atendesse aos interesses dessa pesquisa, assim, foi elaborado um roteiro específico tomando-se por base os seguintes temas para compor a estrutura da entrevista de 16 perguntas: relacionamento interpessoal com a chefia e os colegas de trabalho; formas de reação à injustiça; percepção de justiça organizacional; características de situações relacionadas ao ambiente de trabalho e vivências de violência no trabalho. As perguntas que serviram à entrevista foram:

1. Como vem ocorrendo a modernização da gestão da empresa? É um processo tranqüilo ou conturbado? Descreva um pouco esse momento?

2. Qual é o papel dos colaboradores/servidores/funcionários neste processo? E como você se insere nesse contexto? 
3. Em que medida a empresa busca nas empresas privadas inspiração para o desenvolvimento de sua própria gestão? E sendo incorporadas essas novas ferramentas, quais são os efeitos nos servidores?

4. Qual é o significado do trabalho para você atualmente? E como era o significado no passado?

5. Considerando a atual realidade de sua organização, o que se modificou ou tem se modificado em termos de relações de trabalho e relações pessoais na organização?

6. Há gestão por resultados na empresa? Como ela funciona? Qual é o papel do funcionário? Você se sente reconhecido e recompensado pela sua contribuição no alcance das metas?

7. Considerando que a comunicação é um fator essencial para a organização, qual é a sua visão quanto ao discurso organizacional em recursos humanos? O que a empresa fala para você?

8. O que significa justiça organizacional para você? Pensando sobre isso, você diria que existe uma aplicação igualitária e não enviesada das regras? Você já conheceu alguém que foi injustiçado na organização?

9. O que se modificou ou tem se modificado em termos de relações de trabalho na organização?

10. Qual é a sua visão do controle dos indivíduos na empresa?

11. Você se sente pressionada no trabalho? De que forma? Quais as emoções que você experiência no ambiente de trabalho?

12. Pensando em toda a sua trajetória de trabalho, você já vivenciou alguma espécie de violência no trabalho? Alguma relacionada à gestão? Conhece algum que tenha vivenciado tal situação? 
13. Em que medida a gestão privilegia resultados em detrimento das pessoas na empresa? Como pode ser descrito o sentimento dos servidores nesse contexto?

14. Num contexto de mudanças na sociedade e de intensa competitividade para o alcance da sustentabilidade da organização, a pressão por resultados proporciona a presença de lideranças perversas na organização? Em caso afirmativo, como reagem os servidores? Quais os mecanismos de defesa?

15. Pense na sua organização como um todo, o que você mais percebe como estando presente na organização: vigilância hierárquica, autonomia ou autonomia controlada?

16. Como andam as relações na organização? O coletivo está fragmentado? As reivindicações coletivas cedem espaço para as reivindicações individuais? Existe uma isonomia de justiça ou prevalece a lei de quem pede ganha?

\section{4 - Procedimentos e análise de dados}

As entrevistas foram realizadas de conformidade com o horário e local de acordo com a disponibilidade do servidor entrevistado. Como a organização estava atravessando um período de muita exoneração e disputa interna, foi difícil encontrar servidores com horário disponível para a entrevista. Todos estavam sendo muito demandados em seus postos de trabalho. Apesar desse cenário organizacional, a entrevista teve uma positiva recepção por parte dos servidores que aceitaram participar da pesquisa. 
A entrevista foi precedida de esclarecimento quanto aos objetivos e a natureza da pesquisa, sendo garantido o sigilo das informações sobre os nomes e unidades de lotação. Após os referidos esclarecimentos, foi colhida expressa autorização do servidor entrevistado para a gravação da entrevista. Ao término das entrevistas, todos os discursos foram transcritos, onde em seguida foi efetuada a análise de conteúdo dos dados colhidos, que pela sua natureza deve ser eficaz, rigorosa e precisa, procurando extrair os momentos marcantes do discurso do entrevistado (Richardson, 2008).

A análise de conteúdo tem algumas características metodológicas como a objetividade, a sistematização e inferência. Depois da análise efetuou-se a categorização que segundo Bardin (2008) é uma operação de classificação de elementos constitutivos de um conjunto por diferenciação e, seguidamente, reagrupamento segundo o gênero (analogia), com os critérios previamente definidos que podem ser: semânticos, sintático, léxico e expressivo.

A partir da análise de conteúdo das respostas obtidas nas entrevistas qualitativas individuais com os servidores entrevistados, buscou-se, após a transcrição, construir um quadro para cada entrevista onde apontasse o conteúdo predominante das verbalizações sobre o assunto. Os temas mais repetidos e freqüentes em cada entrevista, com posterior comparação entre as entrevistas realizadas, possibilitaram a construção de categorias gerais. Foi preservado o vocabulário utilizado pelos entrevistados.

Em relação aos procedimentos de análise das respostas obtidas nas entrevistas, foi realizada uma primeira leitura dos textos produzidos pelos informantes, chamada de leitura flutuante. A partir dessa primeira leitura, as intuições foram transformadas em hipóteses a serem validadas ou não pelas etapas 
consecutivas. Das hipóteses formuladas foi possível extrair critérios de classificação dos resultados obtidos em categorias de significação.

Os resultados das análises de conteúdo possibilitaram identificar seis categorias de síntese: desigualdade de tratamento; relação entre superior e subordinado; momento atual da organização; violência no trabalho; emoções vivenciadas no trabalho; falta de gestão por resultados. Para facilitar a compreensão, cada categoria será apresentada e discutida separadamente, utilizando eventualmente o discurso dos entrevistados. 


\section{APRESENTAÇÃO E DISCUSSÃO DOS RESULTADOS}

Os resultados das análises de conteúdo a partir das entrevistas qualitativas com os servidores possibilitaram identificar seis categorias de síntese que encontram-se disponibilizadas no item 'quadro síntese'. São elas: desigualdade de tratamento; relação entre superior e subordinado; momento atual da organização; violência no trabalho; emoções vivenciadas no trabalho; falta de gestão por resultados. Para facilitar a compreensão, cada categoria será apresentada e discutida separadamente, utilizando eventualmente o discurso dos entrevistados. No que coube para evitar a identificação, buscou-se preservar o vocabulário dos entrevistados.

\section{1. - A desigualdade de tratamento}

A percepção de injustiça permeia quase todos os discursos dos entrevistados. A parcialidade nas decisões, a presença de vieses e interesses pessoais das pessoas na tomada de decisão, a aplicação de normas e critérios adotados contemplando apenas um segmento de servidores foi apontada por todos os entrevistados como algo freqüente.

O tratamento diferenciado entre os cargos, mesmo estando a contribuição e resultados de um servidor igual à razão de outrem, a falta de transparência no processo decisório e a falta de critérios claros para a obtenção de 
direitos são pontos fortes da percepção da iniqüidade. Alguns entrevistados pela intensidade de seus relatos tiveram trechos do discurso referente ao tema, aparecendo mais de uma vez.

Tratamento diferenciado de funcionários quanto ao próprio acesso que é feito na Casa em função de uma categoria funcional poder entrar de uma forma por ser dessa categoria, (...), enquanto não podem entrar... tem que entrar com crachá, com identificação por pertencer a outras categorias, inclusive a minha, a qual eu pertenço (Entrevistado 04)

Justiça para mim do trabalho é quando você tem, dentro das suas competências, das suas limitações, a gente tem um limite de atuação, o reconhecimento, quer dizer, o direito de trabalhar $e$ exercer aquilo. $\mathrm{Na}$ organização eu acho que, por causa dessa confusão das duas categorias, eu vejo que uma categoria sempre está por cima... quer sobrepor a outra, e para os eles nada mais justo que, como eles estão lá, estão por cima, então eles querem para eles (Entrevistado 06)

A colaboração do pessoal da organização, dos funcionários está sendo muito pouco. Estão se fazendo mais é em relação à vontade dos dirigentes. A participação do funcionário em si quase não tem (Entrevistado 06)

Normalmente as modernizações não têm sido discutidas num sentido mais amplo, então ficam sempre restritas a um grupo e nem sempre elas são bem absorvidas pelos funcionários, pelos servidores (Entrevistado 01)

Eu, na minha visão, hoje, tem uma isonomia de justiça, mas em alguns momentozinhos ainda tem essa outra aí, tem um (...) de "quem pede, ganha", de uma maneira bem discreta mas ainda tem (Entrevistado 07)

A aplicação das regras é completamente enviesada porque quantos do meu cargo já foram para o exterior? Fazer curso, pós-graduação? A gente vê muito pouco em uma categoria, mas da outra...(Entrevistado 04)

Não existe isonomia e nem sempre quem pede ganha. É..., na verdade depende da reivindicação, quando a reivindicação tem amparo, e que não vai expor a pessoa que toma aquele ato discricionário (...), se a pessoa que é responsável por adotar aquele ato discricionário não está submetida a outras inspeções, que ela se sente segura, ela pode conceder para um e não conceder para o outro, na mesma situação, já que é uma discricionariedade (Entrevistado 01) 
Em relação às injustiças sofridas por parte dos servidores surgiram questões referentes às exonerações ocorridas com viés político e excesso de hierarquia autoritária por parte da organização.

Eu sei de várias injustiças que já aconteceram, várias, num tempo muito recente, agora (...) que eu considero uma injustiça foi ter exonerado a (...) por ter sido leal à chefia dela (Entrevistado 02)

Eu já conheci, inclusive atualmente, na mudança dessa nova... não esta última agora, mas na mudança da... quando saiu o gestor maior da organização eu vi gente ser injustiçado. E lamentavelmente eu achei que foi assim, degradante para a pessoa, e a organização estava perdendo gente com isso (Entrevistado 06)

Vários foram injustiçados, vários, e isso é a rotina..., principalmente pelo sentido de hierarquia muito forte, inclusive a hierarquia em relação a cargos, os conflitos não só interpessoais mais organizacionais também, intra-organizacionais, então é uma coisa, é uma situação recorrente e casos de injustiça e de aplicação de forma diferenciada, principalmente dos direitos existem (Entrevistado 05)

$\mathrm{Na}$ gestão anterior, eu posso até ter presenciado algumas coisas mas do lado de lá pode ser que o servidor tenha contribuído para alguma coisa, então por isso que eu prefiro não me adentrar muito nesse item porque eu posso até levar para um caminho de maneira injusta (Entrevistado 07)

No passado as coisas eram um pouco mais democráticas e havia uma valorização das pessoas que produziam. Hoje as pessoas que produzem, elas são relegadas a uma espécie de prisão, um impedimento de progresso na carreira, porque se elas forem substituir, se elas forem tiradas de um lugar para o outro em função das suas capacidades, elas causam um prejuízo a unidade que elas estavam anteriormente, então quem produz alguma coisa hoje, está fadado ao fracasso. O melhor na organização hoje é ficar no meio termo, nem produzir, nem deixar de produzir, porque aí você tem facilidade de ascensão (Entrevistado 01)

Os relatos apontaram para uma desigualdade no trato dos servidores,

levando-os a uma percepção de injustiça tanto, distributiva quanto processual. 


\section{2 - As relações interpessoais}

As relações interpessoais estão relacionadas com a justiça interacional. Esta, segundo a literatura, se divide em dois eixos: tratamento entre superiores e subordinados e comunicação da gerência com os servidores.

Segundo a percepção dos entrevistados a questão de relacionamento interpessoal está deficitária. Existe um segmento de servidores cujo nível de competição é muito elevado, e a maioria considerou o coletivo fragmentado, mas houve a percepção de que as relações estão melhorando por apenas um dos entrevistados. Para Siqueira (2009) os conflitos constantes, os processos de reestruturação organizacional, fusões e a elevada competitividade entre os membros das equipes são alguns dos motivos que levam ao desgaste das forças emocionais dos indivíduos.

Existe uma certa dificuldade de relacionamento com essa fusão. Os últimos concursos, por serem bastante competitivos, eles fizeram com que pessoas muito competitivas entrassem no órgão, e isso no meu ponto de vista, essa visão competitiva aumentou muito dentro da organização (Entrevistado 03)

O coletivo está fragmentado por conta dessas lideranças ou pseudolideranças que acabam contigo, e aí fragiliza muito a unidade, a unidade funcional (Entrevistado 04)

É um momento conturbado porque a gente observa que existe uma rivalidade entre grupos de poder dentro da casa e isso tem causado um pouco de instabilidade nos demais funcionários e isso traz um desconforto muito grande (Entrevistado 04)

O coletivo na organização sempre foi fragmentado, porque foram criados castas e categorias (Entrevistado 06)

O corpo funcional da organização está fragmentado (...) como nunca teve tanto (Entrevista 02)

Os relacionamentos interpessoais, eu vejo de uma forma muito positiva hoje. Inclusive até alguns conflitos que eu vi aqui que eram 
maiores, hoje eu estou sentindo praticamente inexistente (Entrevistado 07)

A relação entre superior e subordinado foi um dos aspectos levantados

no conceito de justiça interacional, percebido pelos entrevistados como uma relação hierárquica intensa, autoritária, e também, ficou evidenciado a falta de gestão por parte do corpo gerencial.

Tem hierarquia no sentido formal, organizacional, mas não tem hierarquia no sentido de responsabilidade, então o papel do administrador de qualquer nível nessa instituição é impor a sua hierarquia em função do papel que ele desempenha temporariamente, ele não tem liderança, ele se vale do mandato, da portaria, da nomeação pra exercer a sua administração, a sua gestão (Entrevistado 01)

Nada mudou. A única coisa que teve uma leve mudança é um acréscimo na hierarquia, houve um acréscimo no papel hierárquico dos administradores, hoje há mais autoritarismo. (Entrevistado 01)

Nas relações de trabalho aumentou muito o tumulto, o que se modificou foi isso, perdeu a coordenação, perdeu o rumo, perdeu considerando o trabalho inócuo, perdeu a coordenação por falta de decisão por cima, paramos de dar orientação, (...) prá baixo ficou perdido por falta de decisão da parte superior (Entrevistado 02)

Em termos de relações de trabalho porque não se sabe o que fazer, não tem apoio da chefia, em relações pessoais também mudou muito com essa história de mudança de administração mudou muita gente (...) saiu gente responsável em termos de relações pessoais já estávamos sentindo há algum tempo, e em termos de relações de trabalho está completamente perdido (...) (Entrevistado 02)

Houve a percepção, por parte de um entrevistado, de lideranças que estão exacerbando do seu papel de gestor em busca do alcance de resultados. 
A busca por resultados, principalmente quem está liderando, a busca daquele resultado, determinadas horas se perde a dimensão do contexto humano, do limite humano e passa-se o atropelo. Eu tenho visto exemplos até muito próximos, onde cada vez eu vejo algumas situações piorarem muito e as pessoas que estão liderando alguns processos nem se quer percebem o que elas estão ocasionando nas pessoas da organização, as mutilações, as dores e as dificuldades que elas estão trazendo para essas pessoas, não é nem uma, duas ou três vezes na semana que as vezes eu paro até fora mesmo do meu ambiente da minha divisão para tentar conversar com algumas pessoas e tentar dar um apoio (Entrevistado 05)

Temos pessoas que estão em determinadas posições dentro da organização, gerenciais ou não, mas algumas posições, vamos chamar assim, de destaque, essas pessoas teriam um histórico de vida onde elas passaram por uma série de situações, em determinados momentos, principalmente na hora de se tornarem gestores, elas esquecem do histórico de vida delas em relação aos seus subordinados e em determinados momentos pela própria questão da guerra do poder, da instabilidade institucional as pessoas tem a capacidade de passarem por cima das outras com uma extrema facilidade (Entrevistado 05)

\section{3 - O momento atual da organização}

$\mathrm{Na}$ opinião dos entrevistados, a organização está sofrendo um emparelhamento político nunca vivenciado pelos servidores em toda a sua história de vida. Isto prejudica a relação da organização com os servidores, assim como, a relação dos servidores com seus pares.

Está sendo de uma forma um pouco tumultuada, não está tranqüilo, mas todo processo de mudança ele nunca é. (Entrevistado 03)

A modernização da gestão da organização é um processo muito conturbado (Entrevistado 06)

Modernização em termos de tecnologia de atualização foi tranqüilo, mas se considerar as mudanças atuais, não está sendo nada tranqüilo (Entrevistado 02) 
A mudança administrativa, com a entrada de uma visão sindical, uma visão política mais forte dentro da organização, vem mudando uma série de paradigmas, de conceitos anteriormente difundidos dentro da Casa, que fez com que surgissem algumas resistências por parte de alguns setores da organização. Há um processo de mudança que não valoriza tanto o lado técnico-profissional quanto se valorizava anteriormente e se valoriza um pouco mais o aspecto político. Então isso gera para alguns servidores um certo grau de insatisfação (Entrevistado 03)

Existe uma, uma influência política muito forte no ambiente organizacional para concretizar os objetivos, além das finalidades do órgão, é o que eu percebo diante dos últimos acontecimentos, de troca de comando da Casa, imposição de aspectos políticos (Entrevistado 04)

Quanto ao caráter informacional da relação superior e subordinados,

buscou-se fazer uma correlação com a organização e seus servidores, no tocante da comunicação organizacional em relação aos seus valores, missão e futuro. Ficou evidente a presença de um hiato nessa questão, gerando instabilidade nos servidores e uma falta de respeito por parte da organização.

É possível presumir que a interferência política no órgão impeça a comunicação institucional de desempenhar o seu papel informativo e valorativo do servidor.

A instituição não tem se comunicado muito bem em relação aos seus objetivos e o que ela pode fazer pelo servidor, o que é muito transmitido são as obrigações funcionais, todo mundo é obrigado a fazer as suas obrigações o seu o papel hierárquico (Entrevistado 01)

Os canais de comunicação não estão liberados, não são livres, as pessoas ainda não estão entendendo exatamente o que viemos, o que fazemos, para que servimos, então está muito complicado e de certa forma até está faltando autoridade num bom sentido, não a autoridade, aquela autoridade maléfica, impositiva, drástica, não, mas aquela autoridade que ela dá rumo, que ela dá a certeza, que ela faz colocações próprias, que ela coloca as pessoas para se sentirem produtivas, então isso está faltando. E no âmbito da alta chefia, da chefia superior, realmente está falando tudo, porque politicamente foi o lado mais atacado, então ainda está muito instável e é claro que isso reflete, vai refletindo para baixo (Entrevistado 05) 
Eu acho que precisa melhorar muito essa questão de comunicação, melhorar muito. Eu não consigo enxergar uma comunicação eficiente nem eficaz (Entrevistado 07)

O discurso é um e a prática é outra e o medo da legalidade é uma coisa que impera nessa casa de uma forma assim exorbitante, então realmente vamos melhorar, seremos melhores, vamos cuidar dos nossos, é o discurso, na hora da prática (,..) vamos imaginar em uma unidade onde tem uma meta clara, ela literalmente existe e ela tem que ser cumprida, então dane-se se a gripe suína chegou e as grávidas estão correndo risco. É um dos grandes exemplos da atualidade (...) a organização nunca teve e ainda não tem política de gestão de pessoas, porque ela ainda não, principalmente, porque ela nem se quer ela consegue comunicar o que ela faz em termos de gestão de pessoas (Entrevistado 05)

Outro conceito levantado pelo discurso dos entrevistados refere-se à gestão por resultados que praticamente é inexistente no órgão. Os entrevistados não foram enfáticos nessa questão, ficaram no meio termo. Alguns disseram que a organização privilegia os resultados a serem alcançados do que os servidores.

Existem tentativas de se fazer gestão por resultados, mas a gente não tem hoje ainda uma ferramenta e essa cultura amplamente difundidas dentro da organização (Entrevistado 03)

Bom, gestão por resultados eu acredito que ela exista em todo lugar. A questão é, a definição desse resultado prévio, que seria a meta, que isso é muito mal feito ou não é feito, e a análise do atendimento dessa meta e do custo dessa meta. Então a organização tem essa mania de que ela é capaz e por ela ser capaz ela vai até o fundo do poço para tentar realizar o que foi solicitado, mas tem coisas que estão custando muito caro e no futuro essa conta pode ser cobrada. (...) Mas isso não é bem planejado, não é bem organizado, não é bem cobrado e não bem analisado, talvez a gente perca muito pela força que a gente gasta para sempre estar reconstruindo e tentando chegar ali naquele modelo que a gente não sabia exatamente o que tinha que fazer (Entrevistado 05)

A organização busca pouco na iniciativa privada e talvez realmente não existam muitos modelo para buscar, talvez seja realmente muito complicado fazer essas adaptações (...) O pior que eu acho é que as vezes, os pouco modelos que a gente tem a capacidade de ir buscar lá fora, quando a gente interioriza, a gente deturpa , a gente usa da pior maneira (..) pegar um exemplo do ponto eletrônico (...) é uma 
ferramenta boa, porque na iniciativa privada você converte num banco de horas e quando chega aqui dentro você puxa um controle excessivo e você abandona o banco de horas que é a parte da compensação com o servidor. Então você acaba negativando um instrumento que seria extremamente positivo (Entrevistado 05)

Não vejo que aqui privilegie resultados, mas também não vejo que valorize as pessoas, não está nem um nem outro (Entrevistado 02)

Essa nova gestão vem com um projeto muito bom, muito bom mesmo, mas está em uma fase muito embrionária, não sinto ainda na área de gestão de pessoas essa modernização ocorrendo (Entrevistado 07)

Não existe nada da empresa privada aqui, tirando agora essa pesquisa (...), não se a gente for pensar, estamos atrasados, tem muita coisa aí fora que a gente não está fazendo aqui (...) você faz o que está fazendo sempre, não vejo inovação (Entrevistado 02)

$\mathrm{Na}$ organização, se busca muito mais o resultado porque nós não somos cobrados só internamente, nós somos cobrados por fora, pelo lado externo, do governo, da sociedade (Entrevistado 06)

\section{4 - A violência no trabalho}

Para todos os entrevistados houve um relato de violência. Alguns foram os protagonistas e outros foram espectadores ou ouvintes das situações. Diante dos discursos se percebe o nível de violência na organização. Houve xingamentos, gritos, coação e até chegaram às 'vias de fato'. Muitos servidores estão usuários de ansiolíticos para suportarem as pressões e as relações interpessoais desprovidas de respeito e ética.

Se uma pessoa é retirada de um cargo por videoconferência, (...), então talvez isso seria uma forma de violência, não seria a forma mais delicada e razoável de se fazer isso. A pessoa pode sentir isso como uma agressão, como uma falta de respeito.(Entrevistado 03) 
Foi demitido sem sequer ter sido conversado com ele, isso não deixa de ser para uma pessoa que trabalhava 14 horas por dia, isso não deixa de ser uma forma de violência administrativa. Esse tipo de comportamento infelizmente nos últimos... um ano, um ano e meio parece que se tornou uma constante.(Entrevistado 03)

Injustiçado no sentido de não terem reconhecido os seus méritos, não terem sido ouvidas as opiniões, e causando uma baixa na auto estima, de um.., de vários, são vários exemplos que eu conheço disso, de auto estima baixa e desincentivando essas novas iniciativas de mudança (Entrevistado 04)

Conheço gente que vivenciou a violência quase partindo para a briga, discussões muito fortes, xingamentos, se sentiram tolhidos naquilo que eles acharam que deveriam ter direito (Entrevistado 04)

Eu vivi violência no trabalho, foi horrível, dificílimo de superar, precisei de muito amigos do meu lado, muito antes do processo, do que está acontecendo hoje, da gestão ter iniciado, foi um momento especifico, me causou muitas perdas dentro do ambiente de trabalho...Perdas muito fortes. Tive que, a partir daí, tive que fazer alguns tratamentos, até bem mais fortes porque..., imaginei até em algum momento, até mesmo abandonar o órgão (Entrevistado 05)

$\mathrm{Na}$ fase atual, eu praticamente, neste momento, estou há um ano sob efeito de medicação, na busca desse equilíbrio, para esperar que essa onda passe, para que a gente tente voltar à normalidade sem desistir do desafio que é tratar dessa inovação, que é tratar dessa modernidade de órgão. Mas a pressão é muito forte, é muito complicada, eu tenho varias pessoas que trabalham ao meu redor e todas essas pessoas estão buscando apoio profissional, estão também sob efeito de medicação, mais ou menos dentro desse mesmo período.. é um momento muito difícil, tem horas que você tem que fazer aquela psicologia pessoal, para poder dar uma calibrada para poder voltar e encarar a normalidade, principalmente pela falta de respeito as individualidades, não só a individualidade do ser humano, mas a individualidades das unidades (Entrevistado 05)

Injustiçados conheço vários. Um não, eu conheço vários injustiçados, eu conheço gente que já foi demitido porque trabalhou e eu conheço gente que não trabalha e que tem reconhecimento todos os dias, não faz nada e a organização está sempre reconhecendo. Eu conheço gente que já foi demitido e sofreu processo administrativo, por trabalhar e conheço gente que já foi punido na organização por ser honesto, se fosse desonesto, era esperto, mas como foi honesto, passou por bobo e acabou processado também e foi injustiçado (Entrevistado 01)

Existe um controle severo sobre as atitudes dos indivíduos, com o pretexto de purificar a organização, de realizar uma atitude correcional, mas na verdade o que acontece com bastante freqüência maior é uma inquisição, hoje nós vivemos num ambiente inquisitório, eu vou dar um exemplo, onde eu trabalho nós respondemos consultas vidas de contribuintes, consultas, pedidos, solicitações, quando o contribuinte tem razão nós somos obrigados a 
dizer não, se dissermos sim a corregedoria nos processa (Entrevistado 01)

$\mathrm{Na}$ gestão anterior eu, eu sofri alguma violência no bom sentido da palavra, é...(pausa) um assédio moral, eu posso definir. Conheço também algumas colegas, alguns colegas também (Entrevistado 07)

Já vivi coação, em vários graus aqui, tanto na situação atual, quanto na situação anterior eu sofri coação. Eu já sofri intimidação aqui, eu já fui ofendido moralmente dentro dessa instituição por superiores, ok?, eu já fui conferido a trabalhar fora do meu horário de trabalho sem remuneração (...) Eu já sofri vários tipos de violências aqui, vários. Eu já fui obrigado a viajar sem dinheiro, sem diária, porque não tinha diária no orçamento, mas me obrigaram a viajar assim mesmo, e sofri vários tipos de coação. (Entrevistado 01)

Eu conheci pessoas que pisavam na cabeça dos outros para subir. Mas isso aí, graças a Deus, se você pegasse 100 e tirasse meio, era muito. Mas existe, não tem jeito, então eu acho que em toda organização tem, mas dentro da nossa organização ela foi muito sufocada. Podia até existir na cabeça das pessoas, mas pela necessidade da convivência não falavam, ou não expunham, ou não faziam esse tipo de coisa (Entrevistado 06)

\section{5 - As emoções vivenciadas no trabalho}

Para a maioria dos entrevistados a emoções vivenciadas no trabalho estão diretamente relacionadas com os processos de trabalho e com as relações interpessoais. Alguns entrevistados se sentem recompensados e reconhecidos, porém outros se sentem pressionados, descrentes quanto ao futuro do órgão. Alguns sentem tristeza, angústia, decepção e até depressão.

Foi levantado que uma grande parte dos servidores da organização pode estar com sentimento de menos valia, cansaço, falta de esperança e de vontade. 
Eu me sinto recompensado, me sinto, desde que eu entrei no serviço público, em todas as áreas que passei meu trabalho sempre foi muito bem reconhecido, e isso claro que deixa a gente bastante satisfeito (Entrevistado 03)

Existe um nível de descrença quanto à visão de futuro que a Casa tem apontado (Entrevistado 04)

Pressionada hoje, até que eu não me sinto pressionada não, mas eu me sinto angustiada, pela falta de definição e pela falta de ação do superior (Entrevistado 02)

As pessoas que eram envolvidas nos processos anteriores foram deslocadas, sem muita cerimônia, ou seja, desvalorizando a história desses funcionários na Casa. Então isso assim, se fizeram com as pessoas que tem competência, imagina com os que ainda estão começando a vir agora (Entrevistado 04)

É uma decepção que eu estou tendo, outros interesses muito escusos podem estar conduzindo algumas ações no sentido da vaidade, e aí vai outros desvios morais das pessoas (Entrevistado 04)

Recompensada, eu já me senti mais. Hoje a situação, principalmente no núcleo que nós estamos vivendo está mais complicada (Entrevistado 05)

Metas, a gente não tem uma meta definida, mas particularmente o meu trabalho, graças a Deus, é muito reconhecido (Entrevistado 07)

$\mathrm{Na}$ atribuição anterior eu estava me sentindo bastante pressionada. Não pelos meus superiores, é que a própria atribuição por envolver algumas entidades fora ao contexto de trabalho fazia com que houvesse uma pressão (Entrevistado 07)

Eu até me sinto recompensada, mas como já falei, a carga está muito grande (Entrevistado 02)

Eu sou pressionado, eu sou pressionado justamente por essa questão de caráter ou não, não ter liberdade nem segurança para dizer a verdade, isso é um tipo de constrangimento muito grande, às vezes dá vontade de não trabalhar, quando a gente é obrigado a arranjar argumentos para mudar alguma coisa que é justa (...) A emoção que sinto é constrangimento, tristeza, e até certo ponto depressão também...(Entrevistado 01)

Trinta, entre trinta e quarenta por cento do corpo funcional da casa que tem bem mais de vinte anos (...) digamos assim, existe um passado, existe uma linha histórica que nem sempre permite que as pessoas colaborem do jeito que poderiam, e isso em razão da fadiga pessoal dessas pessoas, da falta da ...,(pausa) de até mesmo de 
esperança, de vontade, de já estarem cansados de verem tantos modelos fracassando ao longo da vida delas (Entrevistado 05)

Em relação às estratégias de enfrentamento, os servidores adquirem uma postura de adaptação, de aceitação conforme se percebe nos trechos das entrevistas.

O papel dos colaboradores, servidores, funcionários no processo de modernização é nenhum, só de aceitação. (...) Alguns poucos participam do processo de modificação, de modernização, mas essa modificação sempre fica restrita a esfera mais superior da organização. Então, a grande maioria das pessoas, só está tendo o papel de incorporar essas mudanças, de adaptar essas mudanças. A organização nunca se adaptou ao servidor, sempre é o servidor que vai se adaptando a organização(...) eu não participo da decisão, eu não participo da escolha, mas tenho que me adaptar as modificações (Entrevistado 01)

Abordou-se num dos relatos a vivência de violência relativa às condições de trabalho ligadas à ética, que segundo Siqueira (2009, p. 198), "o indivíduo se violenta ao realizar um trabalho não ético ou que possa prejudicar o bem estar social, em virtude das ambições da empresa".

Hoje não me sinto pressionado, hoje a pressão é minha mesmo. Mas antes na outra unidade em que estava, quando a política começa a imperar, você tem que atender a alguém de qualquer jeito, e não pelas ações normais. Então tivemos lá muita pressão (...) quer dizer, a pressão, como eu vou dizer, é mais psicológica. É a pressão da autoridade, obstáculo da autoridade. E eu atender o colega é simples. Eu posso dizer "não", até "não" pra ele. Mas para o superior fica difícil. Politicamente difícil (Entrevistado 06) 


\section{6 - O significado do trabalho}

Para Gaulejac (2007) o trabalho transformou-se num elemento essencial para fixar a posição do indivíduo na sociedade, e também, para canalizar as finalidades da existência sobre a carreira profissional.

O indivíduo durante a sua vida, segundo Siqueira (2009, p. 62), "vai estar buscando reconhecimento, aceitação dos pares e o desenvolvimento do sentimento de ser útil, de estar fazendo algo importante".

Houve relato de que o trabalho significava apenas ganhar dinheiro. No entanto, como foi dito, é também uma fonte de reconhecimento, satisfação e orgulho por pertencer a algum lugar. Alguns continuam com essa convicção, porém outros, por estarem passando por momentos de excessiva pressão e decepção, relatam que estão desmotivados, indo trabalhar porque é preciso.

O trabalho para mim não é só ganhar dinheiro. Tem que receber por aquilo que você faz, mas você tem que gostar, e eu realmente hoje estou numa área que eu gosto (Entrevistado 03)

Eu sempre busquei criar uma motivação própria, para sempre buscar uma espécie de utilidade naquilo que eu posso fazer, sempre visualizar um objetivo útil daquilo que eu estou fazendo para a organização (Entrevistado 04)

Antigamente nós éramos da elite do serviço público, hoje nós somos mais um. E acho que o nosso brilho, o nosso orgulho está lá embaixo (Entrevistado 06)

Era bem mais tranqüilo, o significado do trabalho (...) eu gosto do meu trabalho, mas hoje falando especificamente eu, está uma sobrecarga inclusive psicológica muito grande (...) antes eu tinha que trabalhar e pronto (...) hoje não está tão gratificante (Entrevistado 02)

Hoje o trabalho para mim é apenas um meio de ganhar o sustento. Eu não tenho mais nenhum tipo de prazer no trabalho. Então, eu uso o trabalho somente como meio de sustentar economicamente a minha vida. Antigamente eu tinha, eu tinha uma certa ... Vamos supor, eu tinha uma atitude diferente, eu considerava que trabalhar 
também fazia parte de um universo de reconhecimento, de retorno, mas há muitos anos eu não tenho esse retorno (Entrevistado 01)

Eu realmente tenho um orgulho gigantesco de trabalhar na organização, então realmente e eu tento dar manutenção nessa situação para que eu nunca perca essa vontade e o que eu sinto em relação a isso para cá é, é lógico que com todo esse processo dos últimos anos na organização o que a gente está vivendo, a organização de hoje não é a organização que eu entrei. Agora eu também não tenho uma posição totalmente firmada que ela é pior ou eu ela é melhor (Entrevistado 05)

\section{7 - Quadro síntese}

\begin{tabular}{|c|c|c|}
\hline CATEGORIA & CONTEÚDO & VERBALIZAÇÃO \\
\hline $\begin{array}{l}\text { desigualdade de } \\
\text { tratamento }\end{array}$ & $\begin{array}{l}\text { tratamento } \\
\text { diferenciado } \\
\text { falta de critério para } \\
\text { cargo comissionado } \\
\text {.falta de isonomia na } \\
\text { aplicação dos } \\
\text { direitos do servidor } \\
\text { capacitação } \\
\text { direcionada para } \\
\text { "castas" }\end{array}$ & $\begin{array}{l}\text { "Tratamento diferenciado de funcionários quanto ao próprio acesso que é feito } \\
\text { na Casa em função de uma categoria funcional..." } \\
\text { "...então quem produz alguma coisa hoje, está fadado ao fracasso. O melhor na } \\
\text { organização hoje é ficar no meio termo, nem produzir, nem deixar de produzir, } \\
\text { porque aí você tem facilidade de ascensão" } \\
\text { "Estão se fazendo mais é em relação à vontade dos dirigentes. A participação do } \\
\text { funcionário em si quase não tem..." } \\
\text { "A aplicação das regras é enviesada, porquê quantos do meu cargo já foram } \\
\text { para o exterior? Fazer curso, pós-graduação?..." }\end{array}$ \\
\hline $\begin{array}{c}\text { relação } \\
\text { interpessoais }\end{array}$ & $\begin{array}{l}\text {.alta competitividade } \\
\text { entre os cargos } \\
\text {.exacerbação do } \\
\text { papel do gestor } \\
\text {.excesso de controle } \\
\text { e autoridade } \\
\text { coletivo } \\
\text { fragmentado } \\
\text {.ausência de } \\
\text { decisão e orientação } \\
\text { do superior }\end{array}$ & $\begin{array}{l}\text { "Os últimos concursos, por serem bastante competitivos, eles fizeram com que } \\
\text { pessoas muito competitivas entrassem no órgão(,...).essa visão competitiva } \\
\text { aumentou muito dentro da organização" } \\
\text { "...as pessoas que estão liderando alguns processos nem se quer percebem o } \\
\text { que elas estão ocasionando nas pessoas da organização, as mutilações, as } \\
\text { dores e as dificuldades que elas estão trazendo para essas pessoas" } \\
\text { "O coletivo está fragmentado por conta dessas lideranças ou pseudo-lideranças } \\
\text { que acabam contigo, e aí fragiliza muito a unidade..." } \\
\text { "Em termos de relações de trabalho porque não se sabe o que fazer, não tem } \\
\text { apoio da chefia, em relações pessoais também mudou muito com essa história } \\
\text { de mudança de administração mudou muita gente (...) saiu gente" }\end{array}$ \\
\hline $\begin{array}{l}\text { momento atual } \\
\text { da organização }\end{array}$ & $\begin{array}{l}\text {.emparelhamento } \\
\text { político } \\
\text {.falta de clareza nas } \\
\text { diretrizes } \\
\text {.ausência de política } \\
\text { de valorização dos } \\
\text { servidores }\end{array}$ & $\begin{array}{l}\text { "Existe uma, uma influência política muito forte no ambiente organizacional para } \\
\text { concretizar os objetivos, além das finalidades do órgão..." } \\
\text { "Não vejo que aqui privilegie resultados, mas também não vejo que valorize as } \\
\text { pessoas, não está nem um nem outro" } \\
\text { "Os canais de comunicação não estão liberados, não são livres, as pessoas } \\
\text { ainda não estão entendendo exatamente o que viemos, o que fazemos, para que }\end{array}$ \\
\hline
\end{tabular}




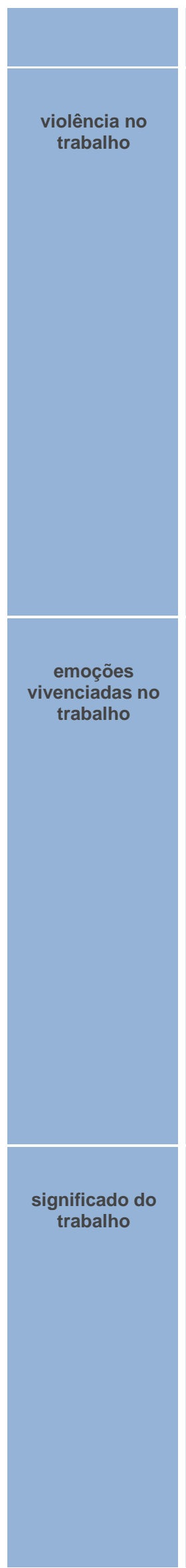

servimos, então está muito complicado"

. exoneração injusta e sem respeito

.servidores usuários de drogas lícitas (ansiolítico...)

.ausência de ética

.intimidação,

coação, ofensa

moral e assédio moral

.controle excessivo

.descrença

tristeza

.falta de esperança

.adaptação

.angustia

.desvalorização

.insegurança

.decepção

.vaidade

.pressão

.constrangimento

ser útil

.atualmente meio de sustento

sentido de pertencimento
"Foi demitido sem sequer ter sido conversado com ele, isso não deixa de ser para uma pessoa que trabalhava 14 horas por dia, isso não deixa de ser uma forma de violência..."

"Na fase atual, eu praticamente, neste momento, estou a um ano sob efeito de medicação, na busca desse equilíbrio, (...). Mas a pressão é muito forte, é muito complicada, eu tenho varias pessoas que trabalham ao meu redor e todas (...) estão buscando apoio profissional, estão também sob efeito de medicação, mais ou menos dentro desse mesmo período.."

"Eu conheço gente que já foi demitido e sofreu processo administrativo, por trabalhar e conheço gente que já foi punido na organização por ser honesto, se fosse desonesto, era esperto"

"Existe um controle severo sobre as atitudes dos indivíduos, com o pretexto de purificar a organização, de realizar uma atitude correcional, mas na verdade o que acontece com bastante freqüência maior é uma inquisição"

“...você tem que atender a alguém de qualquer jeito, e não pelas ações normais. Então tivemos lá muita pressão (...) quer dizer, a pressão, como eu vou dizer, é mais psicológica. É a pressão da autoridade..."

\section{"Existe um nível de descrença quanto à visão de futuro..."}

“...até que eu não me sinto pressionada não, mas eu me sinto angustiada, pela falta de definição e pela falta de ação do superior"

"As pessoas que eram envolvidas nos processos anteriores foram deslocadas, sem muita cerimônia, ou seja, desvalorizando a história desses funcionários na Casa. Então isso assim, se fizeram com as pessoas que tem competência, imagina com os que ainda estão começando a vir agora"

"É uma decepção que eu estou tendo, outros interesses muito escusos podem estar conduzindo algumas ações no sentido da vaidade, e aí vai outros desvios morais das pessoas"

"Eu sou pressionado justamente por essa questão de caráter ou não, não ter liberdade nem segurança para dizer a verdade, isso é um tipo de constrangimento muito grande, às vezes dá vontade de não trabalhar, quando a gente é obrigado a arranjar argumentos para mudar alguma coisa que é justa (...) A emoção que sinto é constrangimento, tristeza, e até certo ponto depressão também..."

"...buscar uma espécie de utilidade naquilo que eu posso fazer, sempre visualizar um objetivo útil daquilo que eu estou fazendo..."

"Antigamente nós éramos da elite do serviço público, hoje nós somos mais um (...) o nosso orgulho está lá embaixo"

"Hoje o trabalho para mim é apenas um meio de ganhar o sustento."

“...eu considerava que trabalhar também fazia parte de um universo de reconhecimento, de retorno"

"Eu realmente tenho um orgulho gigantesco de trabalhar na organização, então realmente e eu tento dar manutenção nessa situação para que eu nunca perca essa vontade" 


\section{CONSIDERAÇÕES FINAIS}

O presente estudo objetivou identificar as possíveis modalidades de violência nas relações de trabalho numa organização pública federal no Distrito Federal. Levando em consideração as limitações da pesquisa, isto é, a realização das entrevistas em apenas uma unidade da organização, uma vez que essa tem representação em todo o território nacional, e a restrição a dois cargos de carreira que constituem uma parte da totalidade dos colaboradores, ainda assim, esse estudo poderá contribuir para ampliar o debate sobre as questões relativas à violência no trabalho num setor pouco estudado, que é setor público.

Pretendeu-se especificamente conhecer e tornar visível o tema, além de resgatar percepções e experiências de justiça e injustiça na organização, da qualidade das relações de trabalho, os sentimentos e emoções vivenciados e respectivas estratégias de enfrentamento, discutindo-os a luz da literatura sobre o assunto. Enfim, expor o que ocorre no ambiente organizacional relativo à (in) justiça e violência para quem sabe, tentar provocar uma reflexão dos dirigentes, especialmente sobre políticas de gestão de pessoas.

A injustiça é percebida pela maioria dos entrevistados servidores da organização pesquisada, principalmente pela discriminação que enfrentam, pois ficou evidente a disputa entre dois cargos dentro da carreira. A cultura do órgão pode fomentar essa disputa. Ela é determinante nos procedimentos organizacionais e pode propiciar situações de conflito interno, a partir da percepção da injustiça pelos seus servidores, afetando, assim, a qualidade de vida no trabalho dos profissionais. 
O serviço público apresenta-se como alternativa de trabalho para grande parte da população ativa, sendo bem remunerado e estável, e, garantindo a sobrevivência do indivíduo. No entanto, como pode ser observado no presente estudo, apesar desses benefícios, o indivíduo poderá vivenciar no contexto da organização, situações que poderão dar origem à violência no trabalho.

Na percepção da maioria dos entrevistados, em resumo, as injustiças podem ser percebidas, da desigualdade de tratamento à falta de comunicação por parte da organização.

Pode-se inferir que as origens das injustiças e violências estão intrinsecamente relacionadas.

As dimensões que mais relacionaram a percepção da justiça organizacional com o surgimento da violência no ambiente de trabalho foram: a justiça interacional e o momento atual da organização, incluindo nesse contexto, a falta de gestão por resultado. Todas elas dão um tom de injustiça aos servidores entrevistados.

Parece correto afirmar que a justiça organizacional desempenha um papel fundamental na qualidade de vida no trabalho dos servidores. Ações que corrigissem e coibissem processos injustos e carregados de vieses seriam uma estratégia inicial na construção de um ambiente mais seguro para a psique humana.

A dimensão justiça interacional refere-se à qualidade de tratamento interpessoal durante as atividades laborais e, também, a comunicação gerencial com os servidores. Tudo isso, ocorrendo no campo do respeito, polidez e honestidade. Verificou-se na organização um desequilíbrio de forças, haja vista, a disputa de poder dentro do órgão, havendo, também, uma hierarquia autoritária que serve apenas aos interesses pessoais do gestor. 
A dimensão momento atual da organização revela o contexto em que os servidores estão inseridos no momento da pesquisa. Conforme foi identificado pelos entrevistados, houve uma tomada política da organização. Tanto políticos, como sindicatos começaram a interferir nas disposições processuais e relacionais da organização. Parece que o órgão tornou-se uma moeda de troca nas coalizões partidárias. A segurança que a organização propiciava aos servidores, não se faz mais percebida por eles. A intensa troca de administradores e gestores leva à descontinuidade dos processos e projetos iniciados. A falta de gestão de resultados percebida por todos os entrevistados é um fator gerador de falta de critério no reconhecimento, de valorização do servidor e um obstáculo no alcance das metas. Percebeu-se que os servidores não sabiam o que fazer, ou se o que estavam fazendo iria agregar valor à organização.

Os servidores entrevistados, apesar de terem revelado suas emoções e violências vivenciadas, mantêm-se produtivos, pela necessidade de cuidar da organização que sentem ou já sentiram orgulho de pertencer, ou talvez, por uma questão de estratégia de enfrentamento, pois trabalhar e produzir faz com que se sintam úteis.

É possível inferir segundo a revisão literária que a implantação do modelo de administração gerencial contribuiu para a ocorrência tanto da injustiça quanto a violência.

Os relatos de vivências de violências no trabalho feitas pelos entrevistados revelaram questões sérias que se desenrolam na organização pública. Tipificar os tipos de violência certamente alcançará várias modalidades descritas no presente estudo, citando alguma delas: o assédio moral, a violência-político burocrática e a violência psicológica. 
Enfim, não se pretendeu com esse estudo fazer um diagnóstico da injustiça e da violência nas relações de trabalho numa organização pública federal, mas cabe sugerir que esses órgãos públicos tenham um novo olhar para os servidores e, também, observem as relações interpessoais e verifiquem se o contexto organizacional é acolhedor, seguro e igualitário em suas deliberações. 


\section{REFERÊNCIAS}

ASSMAR, E. M. L., FERREIRA, M. C., SOUTO, S. O. Justiça Organizacional: uma revisão crítica da literatura. Psicologia: Reflexão e Crítica. Porto Alegre, v. 18, n. 3. 2005.

BARDIN, L. Análise do conteúdo. Lisboa, Edições 70.

BARRETO, M. Violência, Saúde e Trabalho: uma jornada de humilhações. São Paulo: EDUC, 2006.

BIES, R. J., \& MOAG, J. S. Interactional justice: Communication criteria of fairness. In L. Lewicki, B. H. Sheppard., \& M. H. Bazerman (Eds.) Research on negotiation in organizations (pp. 43-55). Greenwich: JAI Press. 1986 apud FERREIRA, M. C.; ASSMAR, E. M. L.; SOUTO, S. O. ; OMAR, A. G.; DELGADO, H. U.; GONZÁLES, A. T.; GALÁZ, M. M. F. Individualismo e Coletivismo, Percepção de Justiça e comprometimeno em Organizações Latino-Americanas. Revista Interamericana de Psicologia/Interamerican Journal of Psychology, v. 40, n. 1, p. 13-24. 2006.

BRANT, L. C.; GOMEZ, C. M. O sofrimento e seus destinos na gestão do trabalho. Ciência e Saúde Coletiva, v.10, n. 4, Rio de Janeiro, out/dez. 2005.

CHANTAL, J. F. O gerencialismo e a ética do bem comum: a questão da motivação para o trabalho nos serviços públicos. 2002. Trabalho apresentado no Congresso Internacional del CLAD sobre la Reforma Del Estado y de la Administración Pública, Lisboa, 2002.

COHEN-CHARASH, Y., \& SPECTOR, P. E. The role of justice in organizations: A meta-analysis. Organizational Behavior and Human Decision Processes. 86, p. 278321. 2001 apud FERREIRA, M. C.; ASSMAR, E. M. L.; SOUTO, S. O. ; OMAR, A. G.; DELGADO, H. U.; GONZÁLES, A. T.; GALÁZ, M. M. F. Individualismo e Coletivismo, Percepção de Justiça e Comprometimeno em Organizações Latino-Americanas. Revista Interamericana de Psicologia/Interamerican Journal of Psychology, v. 40, n. 1, p. 13-24. 2006.

DE PAULA, A. P. P. Por uma nove gestão pública: limites e potencialidades da experiência contemporânea. Rio de Janeiro:FGV,2005 
DEJOURS, C. A., tradução de Luiz Alberto Monjardim. A banalização da injustiça social. Rio de Janeiro: FGV. 2007a.

DI MARTINO, V. Worplace-related violence. New York: Westdeutscher Verlag Wesbaden and Westview Press. 2002a apud GUIMARÃES, L. A. M; RIMOLI, A. O. "Mobbing" (Assédio Psicológico) no Trabalho: Uma síndrome psicossocial multidimensional. Psicologia: Teoria e Pesquisa, v. 22, n. 2, p. 183-191, mai/ago. 2006.

FREITAS, M. E. Assédio Moral e Assédio Sexual: faces do poder perverso nas organizações. RAE - Revista de Administração de Empresas, v. 41, n. 2, p. 8-19, abr/jun. 2001.

12, n. 32, p. 13-27, jan/mar. 2005

Existe uma saúde moral nas organizações? O\&S, Salvador, v.

FREITAS, M. E.; HELOANI, R.; BARRETO, M. Assédio Moral no Trabalho. São Paulo: Cengage Learning, 2008.

GAULEJAC, V. DE. Gestão como Doença Social: ideologia, poder gerencialista e fragmentação social. São Paulo: Idéias \& Letras, 2007.

GUIMARÃES, L. A. M; RIMOLI, A. O. "Mobbing" (Assédio Psicológico) no Trabalho: Uma síndrome psicossocial multidimensional. Psicologia: Teoria e Pesquisa, v. 22, n. 2, p. 183-191, mai/ago. 2006.

HIRIGOYEN, M. F. Assédio Moral: A violência perversa no cotidiano; tradução de Maria Helena Kühner. Rio de Janeiro: Bertrand Brasil, 2002.

Mal-Estar no Trabalho: Redefinindo o assédio moral; tradução de Rejane Janowitzer. Rio de Janeiro: Bertrand Brasil, 2006.

HOEL, H.; COOPER, C. \& FARAGHER, B. The experience of bulling in Great Britain: The impacto $f$ organizational status. European Journal of Work and Organizational Psychology, 10, 443-446 apud GUIMARÃES, L. A. M; RIMOLI, A. O. "Mobbing" (Assédio Psicológico) no Trabalho: Uma síndrome psicossocial multidimensional. Psicologia: Teoria e Pesquisa, v. 22, n. 2, p. 183-191, mai/ago. 2006.

LEATHER, P. Workplace violence: scope, definition and global context. Em L. C. Cooper \& N. Swanson (Orgs), Violence in the health sector: State of the art (pp.3-18). 
Geneva: International Labor Office - ILO. Retirado em 10/05/2004 de http://www.icn.ch/state.pdf apud GUIMARÃES, L. A. M; RIMOLI, A. O. "Mobbing" (Assédio Psicológico) no Trabalho: Uma síndrome psicossocial multidimensional. Psicologia: Teoria e Pesquisa, v. 22, n. 2, p. 183-191, mai/ago. 2006.

MEIRELLES, I. A. C., O impacto das percepções de justiça organizacional sobre as vivências de prazer e sofrimento no trabalho. Dissertação (Mestrado em Psicologia). Departamento de Psicologia, Universidade Católica de Goiás. 2006.

MENDES, A. M.; LIMA, S. C. C. \& FACAS, E. P. (ORG) ET alii. Diálogos em psicodinâmica do trabalho. Brasília: Paralelo, 2007.

MENDES, A. M. (ORG). Psicodinâmica do trabalho: teoria, método e pesquisas. São Paulo: Casa do Psicólogo, 2007

servidão. Curitiba: Juruá, 2008.

Trabalho e Saúde: o sujeito entre a emancipação e

MENDONÇA, H.; MENDES, A. M. Experiências de injustiça, sofrimento e retaliação no contexto uma organização pública do Estado de Goiás. Psicologia em Estudo. v. 10, n.3, p. 489-498, Maringá, set/dez. 2005.

PAOLI, P. \& MERLLIÉ, D. Third European survey on working conditions 2000, Publisher: European Foundation for the Improvement of Living and Working Conditions, Luxembourg: Office for Official Publications of the European Communities. 2001 apud GUIMARÃES, L. A. M; RIMOLI, A. O. "Mobbing" (Assédio Psicológico) no Trabalho: Uma síndrome psicossocial multidimensional. Psicologia: Teoria e Pesquisa, v. 22, n. 2, p. 183-191, mai/ago. 2006.

SCIALPI, D. La violência em La gestión de personal de la administración pública, como condición necesaria para la corrupción. Revista Venezolana de Gerencia, ano 7, n. 18, p. 196-219, 2002.

Disponível em:

http://www.acosomoral.org/pdf/LaviolencialaboralenloA.pdf.

SCIALPI, D. Violência laboral y desamparo institucional aprendido. Revista Jurisprudência Argentina, n. especial: MOBBING EL acoso psicológico em El âmbito laboral, 2005.

Disponível em:

http://www.acosomoral.org/pdf/R\%5B1\%5D.J.A.\%20Abril\%202005.\%20MOBBING\% $\underline{20 \text { (Scialpi).pdf }}$ 
SIQUEIRA, M. V. S. Gestão de Pessoas e discurso organizacional: Crítica à relação indivíduo-empresa nas organizações contemporâneas. $2^{\underline{a}}$ edição, Curitiba: Juruá, 2009.

SIQUEIRA, M. M. M., GOMIDE JR, S. Vínculos do indivíduo com o trabalho e com a organização. In: ZANELLI, J. C., BORGE-ANDRADE, J. E., BASTOS, A. V. B. (Orgs). Psicologia, Organizações e Trabalho no Brasil. Porto Alegre: Artemed, p. 300-328. 2004.

SOARES, L. Q. Interações socioprofissionais e assédio moral no trabalho: ou você interage do jeito deles ou vai ser humilhado até não agüentar mais. São Paulo: Casa do Psicólogo, 2008.

SOBOLL, L. A. P. (ORG). Violência psicológica no trabalho e assédio moral: pesquisas brasileiras. São Paulo: Casa do Psicólogo, 2008.

ZANELLI, J. C., BORGES-ANDRADE, J. E., BASTOS, A. V. B. (Orgs). Psicologia, Organizações e Trabalho no Brasil. Porto Alegre: Artmed, p. 207-236. 2004. 